\title{
Individually tailored internet-based cognitive behavioural therapy for adolescents, young adults and older adults with anxiety
}

\author{
Kristin Silfvernagel
}

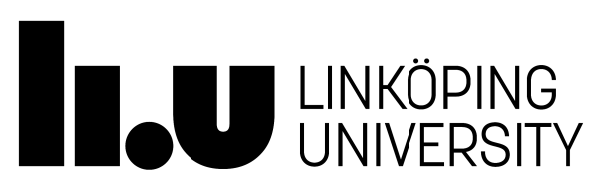

Linköping Studies in Arts and Science No. 710

Linköping Studies in Behavioural Science No. 198

Faculty of Arts and Sciences

Linköping 2017 
Linköping Studies in Arts and Science $\cdot$ No.710

Linköping Studies in Behavioural Science No. 198

At the Faculty of Arts and Sciences at Linköping University, research and doctoral studies are carried out within broad problem areas. Research is organized in interdisciplinary research environments and doctoral studies mainly in graduate schools. Jointly, they publish the series Linköping Studies in Arts and Science. This thesis comes from the Division of Psychology at the Department of Behavioural Sciences and Learning.

Distributed by:

Department of Behavioural Sciences and Learning

Linköping University

58183 Linköping

Kristin Silfvernagel

Individually tailored internet-based cognitive behavioural therapy for adolescents, young adults and older adults with anxiety

Edition 1:1

ISBN 978-91-7685-566-9

ISSN 0282-9800

ISSN 1654-2029

(c) Kristin Silfvernagel

Department of Behavioural Sciences and Learning, 2017

Cover by: Peter Suneson

Printed by: LiU-tryck, Linköping 2017 
- For those who remain, death should never take precedence over life. 


\begin{abstract}
Anxiety disorders share the feature of excessive fear, anxiety and related behavioural disturbances. Fear is defined as the emotional response to a real or a perceived imminent threat and anxiety is the anticipation of a future threat. The anxiety disorders covered in this thesis are panic disorder with or without agoraphobia, social phobia, post-traumatic stress disorder, generalized anxiety disorder and anxiety disorder not otherwise specified.

Cognitive behavioural treatment protocols are typically designed to target one specific disorder and falls under the definition of disorder-specific cognitive behavioural therapy. It is however unclear if this is the most optimal approach in regards to the high comorbidity between anxiety disorders and depressive disorders. Internet-based cognitive behavioural therapy has in the past generally been disorder-specific and from above mentioned predicament two alternative treatment approaches emerged, the tailored and the transdiagnostic approach that aims to simultaneously treat both principal and comorbid disorders. Previous trials on internet-based cognitive behavioural therapy have targeted adults in general and relatively few target adolescents, young adults and older adults.

The aims of this thesis were to further develop and test the effects of tailored internet-based cognitive behavioural therapy on the basis of age, for adolescents, young adults and older adults. Specifically by developing and testing the effects of individually tailored internet-based cognitive behavioural therapy for adolescents with anxiety and comorbid depressive symptoms and by adapting and testing the effects of individually tailored internet-based cognitive behavioural therapy for young adults and older adults with anxiety and comorbid depressive symptoms. These aims were tested in two pilot effectiveness studies (Paper I and III) and two efficacy randomised controlled trials (Paper II and IV). The results from these four trials showed significant results across all outcome measures with overall moderate to large effect sizes. The tentative conclusion based on these results is that tailoring internet-based cognitive behavioural therapy can be a feasible approach in the treatment of anxiety symptoms and comorbid depressive symptoms for adolescents, young adults and older adults. Despite the positive findings of the studies in this thesis, there is a need for more research examining the acceptability and effectiveness of internet-based cognitive behavioural therapy for adolescents, young adults and older adults with anxiety and depression before implementation on a larger scale.
\end{abstract}

Keywords: internet-based treatment, cognitive behavioural therapy, anxiety, adolescents, young adults, older adults 


\section{Empirical studies}

I. Silfvernagel, K., Gren-Landell, M., Emanuelsson, M., Carlbring, P., \& Andersson, G. (2015). Individually tailored internet-based cognitive behavior therapy for adolescents with anxiety disorders: A pilot effectiveness study. Internet Interventions, 2, 297-302.

II. Silfvernagel, K., Carlbring, P., Kabo, J., Edström, S., Eriksson, J., Månson, L., \& Andersson, G. (2012). Individually tailored internet-based treatment for young adults and adults with panic attacks: Randomized controlled trial. Journal of Medical Internet Research, 14 [3], e65.

III. Silfvernagel, K., Wassermann, C., \& Andersson, G. [accepted]. Individually tailored internet-based cognitive behavioural therapy for young adults with anxiety disorders: A pilot effectiveness study. Internet Interventions.

IV. Silfvernagel, K., Westlinder, A., Andersson, S., Bergman, K., Diaz Hernandez, R., Fallhagen, L., Lundqvist, I., Masri, N., Viberg, L., Forsberg, M-L., Lind, M., Berger, T., Carlbring, P., \& Andersson, G. (submitted). Individually tailored internetbased cognitive behaviour therapy for older adults with anxiety and depression: A randomised controlled trial. 


\section{Table of contents}

BACKGROUND 1

Introduction $\quad 1$

$\begin{array}{ll}\text { Anxiety } & 1\end{array}$

$\begin{array}{ll}\text { Comorbidity } & 3\end{array}$

Anxiety during adolescence $\quad 4$

Anxiety during young adulthood 5

Anxiety in late life $\quad 6$

COGNITIVE BEHAVIOURAL THERAPY 7

$\begin{array}{ll}\text { Cognitive behavioural therapy for adolescents } & 7\end{array}$

$\begin{array}{lr}\text { Cognitive behavioural therapy for young adults } & 8\end{array}$

Cognitive behavioural therapy for older adults 9

INTERNET-BASED COGNITIVE BEHAVIOURAL THERAPY 10

Tailored and transdiagnostic internet-based cognitive behavioural therapy

$\begin{array}{ll}\text { SETTING } & 17\end{array}$

OVERALL AIM

EMPIRICAL STUDIES

$\begin{array}{lr}\text { PAPER I. } & 20\end{array}$

$\begin{array}{ll}\text { Aim } & 20\end{array}$

$\begin{array}{ll}\text { Methods } & 20\end{array}$ 
PAPER II. $\quad 25$

$\begin{array}{ll}\text { Aim } & 25\end{array}$

$\begin{array}{ll}\text { Methods } & 25\end{array}$

Results and discussion $\quad 29$

$\begin{array}{ll}\text { PAPER III. } & 31\end{array}$

$\begin{array}{ll}\operatorname{Aim} & 31\end{array}$

$\begin{array}{ll}\text { Methods } & 31\end{array}$

$\begin{array}{ll}\text { Results and discussion } & 35\end{array}$

PAPER IV. $\quad 36$

Aim $\quad 36$

Methods

$\begin{array}{ll}\text { Results and discussion } & 40\end{array}$

GENERAL DISCUSSION

Main findings and conclusions $\quad 42$

$\begin{array}{ll}\text { Limitations } & 44\end{array}$

Future Directions $\quad 46$

REFERENCES 48

ACKNOWLEDGMENTS 


\section{Background}

\section{Introduction}

Internet-based cognitive behaviour therapy (ICBT) (Andersson, 2009) has emerged as a novel evidence-based treatment for anxiety and mood disorders (Andrews, Cuijpers, Craske, McEvoy \& Titov, 2010; Andersson $\&$ Cuijpers, 2009). Guided ICBT has been found to be effective for numerous specific disorders such as panic disorder (Carlbring, Westling, Ljungstrand, Ekselius \& Andersson, 2001; Klein, Richards \& Austin, 2006), generalized anxiety disorder (Robinson et al., 2010; Paxling et al., 2011), social anxiety disorder (Boettcher, Carlbring, Renneberg \& Berger, 2013), post-traumatic stress disorder (Lange et al., 2003) and major depression (Andersson \& Cuijpers, 2009). One limitation of many previous ICBT trials on anxiety and depression is that they targeted specific disorders and that comorbid disorders could either be affected without being directly addressed or remain undetected and unchanged (Titov, Gibson, Andrews \& McEvoy, 2009). Another potential limitation of previous ICBT trials as stated by Carlbring et al. (2006) is that participants with comorbid anxiety and depression disorders are often excluded. Structured or diagnosis-specific ICBT treatments are also limited in that they leave little room for clinician and patient preferences.

One approach to ICBT aims to address these limitations by combining individually tailored treatment according to the participant's needs and symptoms with transdiagnostic components (Carlbring et al., 2011; Johansson et al., 2012; Bergman Nordgren et al., 2014). Previous trials on tailored ICBT have been conducted on an adult population. This thesis examines the effects of tailored ICBT on the basis of age, for adolescents, young adults and older adults.

\section{Anxiety}

Anxiety disorders share the feature of excessive fear, anxiety and related behavioural disturbances (American Psychiatric Association, 2013). Fear is defined as the emotional response to a real or a perceived imminent threat 
and anxiety is the anticipation of a future threat. These states occur simultaneously but vary; fear is associated with autonomic arousal involved in the flight or fight response, thoughts of danger and escape behaviours. Anxiety is more often associated with muscle tension and vigilance in preparation for future danger and avoidant behaviours. Some have a biological vulnerability to react with negative emotions during stress, and to try to alleviate the discomfort the individual feels, they either try to, or escape the situation (Barlow, 2014). Both the biological vulnerability, and the individuals learning history, contribute to the development of anxiety disorders.

The anxiety disorders covered in this thesis are panic disorder with or without agoraphobia, social phobia, post-traumatic stress disorder, generalized anxiety disorder and anxiety disorder not otherwise specified based on the criteria of The Diagnostic and Statistical Manual of Mental Disorders, fourth edition, text revision (DSM-IV-TR; American Psychiatric Association, 2000). Panic attacks are prominently featured within the different anxiety disorders as a fear response and are characterised as a discrete period in which there is a sudden onset of intense apprehension, fearfulness or terror that is often associated with feelings of impending doom. During the attack, symptoms such as accelerated heart rate, sweating, trembling, sensations of shortness of breath, feeling of choking, chest pain, abdominal distress, feeling dizzy, derealisation, fear of losing control, fear of dying, paraesthesia, chills or hot flushes can be present. The different anxiety disorders are distinguished from one another in the types of stimuli that induce fear and anxiety and from the avoidant behaviour present (American Psychiatric Association, 2013). According to the DSM-IV-TR classification system panic disorder with or without agoraphobia is characterised by recurrent unexpected panic attacks from which there is persistent concern (American Psychiatric Association, 2000). Agoraphobia is anxiety about, or avoidance of, places or situations from which escape might be difficult or in which help may not be available in the event of having a panic attack or symptoms of panic. Social phobia is characterised by clinically significant anxiety, provoked by exposure to certain types of social or performance situations, often leading to avoidant behaviour. Posttraumatic stress disorder is characterised by the re-experiencing of an 
extremely traumatic event accompanied by symptoms of increased arousal and by avoidance of stimuli associated with the trauma. Generalized anxiety disorder is characterised by at least 6 months of persistent and excessive anxiety and worry. Anxiety disorder not otherwise specified is a category for prominent anxiety or phobic avoidance for individuals that do not meet criteria for any specific anxiety disorder, but the symptoms are severe enough to warrant a diagnosis of an anxiety disorder.

\section{Comorbidity}

There is now considerable evidence of a complex and reciprocal relationship between anxiety and depression (Katon \& Ciechanowski, 2002; Roy-Byrne et al., 2008). Comorbidity is common in anxiety disorders; between 65-95 percent of individuals who have an anxiety disorder also meet the criteria for another diagnosis (Kovacs \& Devlin, 1998). It is most common to have more than one anxiety disorder. Among young people with anxiety disorder 40-60 percent meet the diagnostic criteria for more than one anxiety disorder at the same time (Wenar \& Kerig, 2008; Rapee, Schniering \& Hudson, 2009). Depression is the second most common comorbid condition of anxiety disorders. Other common comorbid conditions in youths are oppositional defiant disorder, conduct disorder, attention deficit hyperactivity disorder and substance abuse (Rutter et al., 2012; Rapee, Schniering \& Hudson, 2009; Costello et al., 2003). Reflecting the bidirectional relationships between psychological and physical illnesses, the prevalence of chronic health conditions increases with age and having a chronic health condition appears to be one of the strongest risk factors for anxiety and depression (Britt et al., 2008). For example, research indicates that the risk of myocardial infarction increases fourfold among adults with symptoms of depression (Hippisley-Cox et al., 1998). Moreover, depressed patients are three times less likely to adhere to recommended medical treatment regimens for their chronic health conditions than non-depressed patients (DiMatteo et al., 2000). Furthermore, while anxiety and depression are major health issues themselves, untreated anxiety and depression are significant issues among older adults because of their association with poor physical health. 


\section{Anxiety during adolescence}

Epidemiological studies suggest that about 5-19 percent of all children and adolescents have some form of anxiety disorder, which means it is one of the most common psychiatric disorders (James et al., 2015). The median age of onset of any anxiety disorder is 11 years (Kessler et al., 2005; Rickwood $\&$ Bradford, 2012). The presentation of anxiety disorders varies with age (James et al., 2015). Young children can present with indistinguishable worries and fears and multiple somatic symptoms (i.e. muscle tension, headache or stomachache) and sometimes behavioral symptoms (i.e. angry outbursts). The latter may be misdiagnosed as oppositional defiant disorder, as the child tries to avoid anxiety-provoking situations. Social phobia normally appears after puberty. Previous research suggests that adolescents with anxiety are a particularly underserved population that often does not receive adequate treatment for their anxiety (Kendall \& Peterman, 2015) and many cases of social phobia are first diagnosed more than 20 years after onset (James et al., 2015). Distinguishing between normal, developmentally appropriate worries, fears and shyness from anxiety disorders are one of the diagnostic challenges in this age group. Adolescents typically worry and have fears related to school performance, social competence and health issues. Untreated anxiety disorders have a relatively chronic course and adult studies have found that anxiety disorders often have its onset in childhood or adolescence (Wenar \& Kerig, 2008). Adolescents with anxiety disorders also face a range of serious impairments in interpersonal, leisure and academic functioning (Kendall \& Peterman, 2015). To operationalize age groups is a challenge, given the heterogeneity of biological, cognitive, emotional, and social maturity in different age groups and due to the fact that there is no consensus at this point in time. Adolescence is however defined by the World Health Organization as between the ages of 10 and 19 years (Patton et al., 2016). In this thesis adolescence is defined as between the ages of 15 and 19, from the age that an individual can give legal consent for trial participation to the age where the individual is no longer considered an adolescent within the child and psychiatric system in Sweden. 


\section{Anxiety during young adulthood}

Anxiety disorders are among the most common psychiatric disorders in youths (Kendall \& Peterman, 2015). Most individuals who develop an anxiety disorder do so by late adolescence or early adulthood (Seligman \& Ollendick, 2011). Adolescence is by no means a unified transition from childhood to adulthood (Kendall \& Peterman, 2015). Therefore the age group young adult can be considered warranted. In this thesis young adulthood is defined as being aged between 16 and 30, 16 being the youngest age accepted into the youth health care system in Sweden for psychological treatment, and 30 as the upper limit, where most anxiety symptoms have been manifested for the individual. This phase in life is also sometimes described as emerging adulthood; from the late teens to the late twenties when an individual acquires some of the characteristics of adulthood without having reached the milestones that historically define fully fledged adulthood (Patton et al., 2016). Prevalence rates for anxiety in youths vary from 2.4 to 17 percent (Kendall \& Suveg, 2006). Anxiety consists of behavioural, somatic, cognitive and emotional features and one of the most prominent behavioural responses to anxiety is avoidance (Kendall \& Suveg, 2006). Youth with anxiety normally report an increase in autonomic nervous system activity, perspiration, abdominal pain, a flushed face, gastrointestinal distress and trembling. Many youths with anxiety experience cognitive distress (i.e. rumination and excessive worrying). Social phobia become more prevalent after the adolescent has entered puberty but anxiety disorders with onset in childhood normally continue to persist during adolescence and early adulthood if left untreated (James et al., 2015). During the time period of 1994 to 2006 the proportion of young adults aged 16-29 years who reported severe anxiety, more than doubled in Sweden (Swedish National Board of Health and Welfare, 2013). Anxiety in youth, places the individual at an increased risk for comorbid diagnoses, psychopathology in adulthood and lower adaptive functioning in regards to academic/work performance, relations to peers and family relations (Kendall \& Suveg, 2006). 


\section{Anxiety in late life}

Symptoms of anxiety and depression are common among older adults (Skoog, 2011), but are sometimes mistaken for being natural signs of ageing (Law et al., 2010). However, prevalence studies suggest that about 5-10 percent of adults over the age of 65 fulfil the criteria for an anxiety disorder (Schuurmans \& van Balkom, 2011). However, it is argued that the actual prevalence rates may be underestimated in older adults and that many more are likely to experience symptoms of anxiety and depression (O'Connor 2006; Luppa et al., 2012). This is of significant importance since the average life expectancy is set to increase in many countries (Oeppen \& Vaupel, 2002; Porensky et al., 2009). The National Board of Health and Welfare in Sweden (2009) reported that 3-5 percent of adults over 65 years met diagnostic criteria for generalized anxiety disorder and that 10-15 percent experienced late life depression. Anxiety and depression are particularly significant issues among older adults because of their association with poor physical health. Research indicates that anxiety and depression in older adults are associated with poorer physical health and the exacerbation of physical illness (Braam et al., 2005; Brenes et al., 2008) as well as reduced quality of life and increased risk of suicide (Grek, 2007). In older adults, the symptoms are not as prominent as in adults in general (Wolitzky-Taylor et al., 2010). For example, older adults reported less physiological symptoms, use other concepts to describe their experiences and derive the symptoms to somatic diseases. Instead of using the concepts included in the criteria for the disorder, such as "concern" or "uncontrollable", older adults rather use the expressions "problem" and "difficulties" which can lead to misunderstandings and, ultimately, missed diagnoses (Bower, Wetherell, Mon \& Lenze, 2015). Studies on panic disorder in older adults have shown that older adults react with less panic symptoms and have higher functionality compared with younger adults (Lenze \& Wetherell, 2009) and studies on worry content for older adults with or without generalized anxiety disorder show that older adults report a wider variety of worry topics (Diefenbach, Stanley \& Beck, 2001). In this thesis older adults is defined as being of age 60 and above. 


\section{Cognitive behavioural therapy}

In cognitive behavioural therapy (CBT) it is the relationship between thoughts, feelings, behaviours and bodily sensations that are in focus (Wilkinson, 2013). CBT is based on distinctive theoretical frameworks, such as respondent and operant conditioning (Skinner, 1938; Watson \& Rayner, 2000) and information-processing cognitive theories (Beck \& Clark, 1997; Beck \& Haigh, 2014). CBT has its basis in learning psychology, cognitive psychology, and has recently also taken influences from Eastern philosophy; affect theory and dialectics (Westbrook et al., 2011). Modern CBT assumes all these perspectives in the assessment and treatment of mental illness. Based on learning psychology the therapist examines how problem behaviours are perpetuated by contingencies of reinforcement, and based on cognitive psychology, the therapist and patient find how negative thought patterns, presuppositions and rules of life affect the individual. The so-called third wave influenced by Eastern philosophy emphasizes people's struggle to avoid unpleasant feelings and experiences as a cause of mental illness. In CBT all these perspectives are woven into the mapping of the patient's problem, and the patient with the goal of treatment to fit the patient's problems and objectives (Barlow, 2004). CBT is an active treatment for both therapist and patient. Collaboration is emphasized and the patient receives information about both their problems and the purpose of the various interventions (psychoeducation). Homework assignments are an important part of CBT, and the patient makes a large part of the work on their own between sessions.

\section{Cognitive behavioural therapy for adolescents}

Cognitive behavioural therapy has been found to be effective in treating a wide range of mental health problems in adolescents, including anxiety disorders and depression (James et al., 2015). Nonetheless, the majority of individuals with anxiety disorders do not receive evidence-based treatments (Serlachius et al., 2012; Vigerland et al., 2013). Cognitive behavioural therapy for anxiety disorders in children and adolescents often include psychoeducation, affect recognition, cognitive restructuring, relaxation, and graded exposure (Rapee et al., 2009). The treatments used may vary in the extent to which they focus on these components. The general aim, however, 
is to help the patient identify physical, cognitive and behavioural components of the anxiety and then to gradually apply skills to face fearful situations outside the therapy session. Homework assignments are usually included in this process (Rapee et al., 2009) and session numbers may vary from nine to twenty sessions (James et al., 2015). Examples of evidencebased CBT treatments that are manualised for children and adolescents with anxiety disorders include Coping Cat (Kendall, 1994), Friends (Shortt et al., 2001) and Cool Kids (Hudson et al., 2009). These treatments target multiple anxiety disorders and can be administered in groups or individually.

The programs vary in the extent to which they focus on the different skills but the main goal is to help the child identify their symptoms of anxiety and use skills to gradually approach, instead of avoiding the anxiety-provoking situation. Training in other skills such as self-assertion, social skills and problem solving are also frequently included in treatment programs for children and adolescents with anxiety (Rapee, Schniering \& Hudson 2009). Most CBT programs for children include parental involvement to some degree. The established evidence for treatment of anxiety disorders in children and adolescents mainly concern efficacy studies; to date, few effectiveness studies have been conducted in clinical settings (SouthamGerow et al., 2010). In light of the developmental challenges and increased vulnerability to anxiety during adolescence, some have speculated that adolescents may be less responsive to CBT than adults (Kendall \& Peterman, 2015). Adolescents' increasingly busy schedules, marked by extracurricular activities, large academic workloads, and social engagements, may further limit adolescents' willingness to participate in therapy and complete the necessary homework tasks.

\section{Cognitive behavioural therapy for young adults}

The first-line psychological treatment for youth anxiety disorders is cognitive behavioural therapy (Kendall \& Peterman, 2015). CBT for youths has been adapted from adult protocols and addresses symptomatology that cuts across anxiety diagnoses. Specifically, CBT provides psychoeducation about anxiety, teaches youths skills for managing fears (i.e. relaxation, coping thoughts, problem solving, externalization), and provides a context for youths to gradually encounter their fears and minimize avoidance (i.e. 
exposure). The core procedures in cognitive behavioural treatment of anxiety disorders in youth, defined by Woody and Ollendick (2006) and Ollendick and Hovey (2009) are cognitive restructuring, behavioural experiments and repeated exposure, and reduction of avoidance. CBT is present-focused, short-term, and active, requiring youths to participate during in-session and at-home exercises. Although CBT principles are evidence based and standardized, clinicians are encouraged to use "flexibility within fidelity," tailoring treatment to the youth's individual presentation (Kendall et al., 2008). Numerous studies have been conducted to examine CBT for anxiety disorders and anxiety symptoms in youth, and taken together, these studies provide the empirical support necessary to make CBT the only psychological treatment identified to date as an evidence-based treatment (Seligman \& Ollendick, 2011). CBT for anxiety disorders in youth appears efficacious even in the presence of comorbid conditions.

\section{Cognitive behavioural therapy for older adults}

Cognitive behaviour therapy (CBT) is the most widely tested and evidencebased psychological treatment for older adults with anxiety and depression (Shrestha et al., 2011). CBT for older adults is very similar to CBT for adults at other ages, except that it is often modified to include gerontological knowledge and take account of cohort beliefs, physical health status and stage-of-life transitions (Laidlaw et al., 2008) and pleasant activities scheduling (Landreville, Gosselin, Grenier, Hudon \& Lorrain, 2016). Coping strategies are included as well as techniques such as applied relaxation and mindfulness (Bohlmeijer et al., 2003). Several different forms of CBT exist but most involve consideration of maladaptive cognitions, behaviours and physiological response systems. There are some versions of CBT for older adults that have been investigated, for example problem solving therapy (Cuijpers et al., 2007) and reminiscence therapy for depression (Bohlmeijer et al., 2003). More recently, an interest in acceptance-oriented CBT has emerged, but data is still sparse when it comes to older adults. Moreover, it has been argued that older adults tend to benefit somewhat less from CBT than younger adults and that "previously tested intervention protocols may not be adequately tailored to 
accommodate the unique needs of older adults, and greater innovation in psychosocial interventions may be needed" (page 812, Shrestha et al., 2011).

\section{Internet-based cognitive behavioural therapy}

Therapist guided ICBT mirrors CBT but what is unique is the way the treatment is delivered to the patient and how communication is established (Andersson \& Titov, 2014). ICBT require that the patient regularly logon to a secure platform where the patient over a specific time period, access, read and download online materials (i.e. modules). As in CBT the patients receive homework assignments, which they complete before the next module in their treatment. Therapist contact can take the form of real time interventions or as studied in this thesis, delayed interaction that consists of secure and encrypted e-mail communications.

CBT treatment protocols are typically designed to target one specific disorder and falls under the definition of disorder-specific CBT (Dear et al., 2015). It is, however, unclear if this is the most optimal approach in regards to the high comorbidity between anxiety disorders and depressive disorders. Internet-based CBT has in the past generally been disorder-specific and from above mentioned predicament, two alternative treatment approaches emerged, the tailored and the transdiagnostic approach that aims to simultaneously treat both principal and comorbid disorders. Previous trials on ICBT have targeted adults in general and relatively few have targeted adolescents, young adults or older adults.

ICBT for children and adolescents is a small but growing field (Vigerland et al., 2016). These groups are more heterogeneous than adults why there is a need to develop different kinds of treatment and ways to convey them becomes larger. For adolescents and young adults, ICBT has been proven effective for students with social phobia (Tillfors et al., 2011), for students with anxiety, depression and stress (Day, Wojtowicz \& McGrath, 2013), for young adults with anxiety and depression (Sethi, Campbell \& Ellis, 2010), for adolescents with anxiety (Spence et al., 2011) and for adolescents with obsessive-compulsive disorder (Lenhard et al., 2014). 
Few trials have examined the efficacy and effectiveness of ICBT programmes for older adults with anxiety and depression. Programs for individuals aged 60 years and above have been developed in Australia, Sweden (Paper IV) and Canada. The empirical evidence for the efficacy and effectiveness of ICBT for older adults comes from a small number of trials (Dear et al., 2013; Dear et al., 2015 a, b; Titov et al., 2015; Zou et al., 2012; Staples et al., 2016; Titov et al., 2016; Jones, Hadjistavropoulos \& Soucy, 2016). The results of these initial trials are, however encouraging, with moderate to large effects, and highlight the potential of ICBT as an approach of increasing access to evidence-based psychological treatment among older adults.

\section{Tailored and transdiagnostic internet-based cognitive behavioural therapy}

The transdiagnostic approach to treatment is designed to target common underlying symptoms and predisposing psychological factors for anxiety and depression (Pearl \& Norton, 2017). Titov et al. (2012) has transferred this approach to internet-based CBT due to the fact that anxiety and depressive disorders share several characteristics that involve common symptoms, overall course and response to treatment. Transdiagnostic treatment offers potential advantages to disorder-specific approaches with a simplified treatment plan. Several trials have been conducted with transdiagnostic internet-based treatments with promising results (Johnston et al., 2011; Titov et al., 2013; Dear et al., 2015; Păsărelu, Andersson, Bergman Nordgren \& Dobrean, 2016). Internet-based transdiagnostic CBT does not target any specific psychological disorder and is aimed to present a broad range of therapeutic information and skills to the patient (Dear et al., 2015; Fogliati et al., 2016). The information and the skills thought in this treatment format target, cognitive, physical and behavioural symptoms of psychological distress in general.

Tailored internet-based cognitive behavioural therapy is designed to identify a participants unique symptom profile and to provide information and skills that are likely to be helpful based on said profile. This identification is normally based on a diagnostic interview (i.e. SCID, ADIS) and 
measurements (i.e. BAI, MADRS-S) that provide the therapist with information for a behavioural analysis, that in turn guide the therapist in choosing the modules for each participant. There are exceptions to this process; in some cases it has been the participants whom have chosen the modules (Andersson, Estling, Jakobsson, Cuijpers \& Carlbring, 2011). In recent years, this treatment format has been extended to also tailor on the basis of age, specifically for adolescents (Paper I), young adults (Paper II, III) and older adults (Paper IV). The modules in these trials were derived from previous studies on tailored treatment for anxiety and depression (Carlbring et al., 2011; Johansson et al., 2012; Bergman Nordgren et al., 2014). They were adapted for the different age groups both in regards to language and with clinical examples, with different fictitious case examples but sharing the same interventions. The first module (Introduction) and the last module (Relapse prevention) are fixed for all patients and then there are diagnosis and symptom specific modules that the therapist (or the patients in some trials) can choose from. The following are examples of modules that have been prescribed in the trials in this thesis: Cognitive restructuring (2 modules), Generalized anxiety (3 modules), Worrying (1 module), Social anxiety (2 modules), Panic disorder (2 modules), Panic symptoms (1 module), Agoraphobia (1 module), Applied relaxation (1 module), Behavioural activation (2 modules), Procrastination (1 module), Trauma (2 modules), Setting boundaries (1 module), Establish a better sleep pattern (1 module), Mindfulness (1 module), Problem solving (1 module) and Stress (1 module). The modules are all based on established and evidence-based CBT interventions and modules contain relevant components like psychoeducation, exposure exercises and behavioural experiments. All modules contain homework assignments for the participants, which consist of questions on the psychoeducational sections and tasks for the participant to complete. For a detailed description of the modules, see Table 1. 
Table 1

Tailored internet-based treatment, a description of available modules.

\begin{tabular}{|c|c|}
\hline Module(s) & Description \\
\hline Introduction & $\begin{array}{l}\text { A brief presentation on how ICBT is } \\
\text { structured with text modules and } \\
\text { homework. The concept of anxiety is } \\
\text { introduced and different symptoms } \\
\text { and possible causes are described. } \\
\text { The basics of CBT are described and } \\
\text { information on how to set goals is } \\
\text { given. }\end{array}$ \\
\hline Cognitive restructuring 1 and 2 & $\begin{array}{l}\text { These modules explain the } \\
\text { relationship between thoughts and } \\
\text { feelings. Furthermore, the concept of } \\
\text { automatic thoughts and a model to } \\
\text { acknowledge them are presented. The } \\
\text { modules then explain how anxiety is } \\
\text { maintained via a cognitive model and } \\
\text { include strategies to challenge } \\
\text { negative automatic thoughts. }\end{array}$ \\
\hline Generalized anxiety 1, 2 and 3 & $\begin{array}{l}\text { The first module introduces the } \\
\text { concept of anxiety and generalized } \\
\text { anxiety, and information is given } \\
\text { about the potential causes for concern } \\
\text { and how generalized anxiety arises. } \\
\text { In one exercise, the participants make } \\
\text { their own behavioural analysis where } \\
\text { they start from a situation with } \\
\text { concern and describe what happens } \\
\text { to the thoughts, feelings and physical } \\
\text { reactions. Thereafter, the participants } \\
\text { explain what they do when they are } \\
\text { worrying and what effect that has on } \\
\text { them. } \\
\text { In the second module on generalized } \\
\text { anxiety, strategies for reducing } \\
\text { worrying using planned worrying and } \\
\text { worry free zones are presented. } \\
\text { Participants may schedule their }\end{array}$ \\
\hline
\end{tabular}


Worrying

Social anxiety 1 and 2

Panic 1 and 2

Panic symptoms worrying, keep a diary of their worrying and postpone their worrying to a given time.

In the third module, participants learn to expose themselves to their worrying in order to reduce it. Participants are trained how to handle alarming situations without mentally escaping them. Participants are also encouraged to continue with scheduled worrying.

This module is a generic short version of the modules on generalized anxiety for participants who worry but do not meet the criteria for generalized anxiety disorder.

The most common symptoms, problem areas and safety behaviours in social anxiety are presented in this module. The principles of exposure are taught and information is given on how to create an anxiety hierarchy.

The second module describes a cognitive model of social anxiety with the aim of providing a thorough knowledge of what maintains maladaptive behaviours. In various exercises, participants practice shifting focus from themselves to the surroundings in order to become less anxious and self-conscious.

These modules provide psychoeducation on panic disorder. Participants are then guided in interoceptive exposure.

This module provides participants with the knowledge of what panic attacks are and how panic attacks are linked to breathing. In this module, the participant implements various 
Agoraphobia

Applied relaxation

Behavioural activation 1 and 2

Procrastination breathing tests to investigate if this provokes panic symptoms and the participants get knowledge of hyperventilation during panic attacks and how to stop this by regulated breathing.

In this module the participant is presented with information about agoraphobia and the consequences of avoiding different situations. Types of safety behaviours are described and their implications. Exposure guidelines are presented as well as how to design goals for exposure.

This module introduces how to use applied relaxation to reduce anxiety/worrying. The module contains an audio file. Participants are encouraged to practice relaxation daily and continuously evaluate their effects.

These modules begin by describing depression, its causes and consequences from a CBT perspective. The aim of behavioural activation is explained. Participants list preferred behaviours and register them in their activity plan.

In the second module of behavioural activation, participants continue the development of their activity plan. They receive information on how they can reward themselves for the implementation of activities and they are encouraged to evaluate and develop their activity plan.

The module provides psychoeducation about behavioural patterns of postponing activities or tasks. Strategies for handling procrastination are then introduced. 
Trauma 1 and 2

Setting boundaries

Establish a better sleep pattern

Mindfulness
In the first module, participants are given psychoeducation about posttraumatic stress symptoms and common reactions after a trauma. The participants are then guided in exposure exercises and the module provides information about common problems that may arise during exposure.

In the second module, participants use cognitive restructuring as a way to relate different to their thoughts about their trauma.

This module is aimed towards participants who have difficulty setting boundaries. Advice on setting boundaries and concrete techniques for saying 'no' are presented in the module. Furthermore, the module focuses on relationships and how to create and maintain good relationships while maintaining selfrespect.

In this module, the participant is given psychoeducation about sleep and sleep hygiene. The participant must then identify their sleep pattern and examine the factors that influence their sleep patterns and what needs to change. Different sleep strategies are presented, and participants are encouraged to test the strategies that seem appropriate based on their own sleep patterns.

In this module, participants are introduced to mindfulness and the module consists of several mindfulness exercises. The exercises focus on different areas: the breathing, the body and emotions. For each exercise, there are audio files that can be used as guidance. 
Problem solving

Stress

Relapse prevention
In this module, the participants practice problem-solving skills as a means of coping with stressful problems.

In this module, the participants receive psychoeducation about stress. The participant then identifies situations that cause them stress. The module highlights the importance of a balance between rest and activity and sets an action plan to accomplish this. The module also has a section with work related stress and concrete advice is given on how stress can be reduced.

The final module describes the difference between setbacks and relapse. Common risk situations for setbacks are described as well as general strategies for dealing with these. Participants are encouraged to summarize their treatment where they are asked to describe what was most important to them based on modules they have gone through. Participants are also invited to go through what they have learned and make a written plan of action for the future.

\section{Setting}

Guided ICBT has been investigated in more than 100 controlled efficacy studies (Hedman et al., 2012). In these efficacy studies internal validity is prioritized, which means that experimental control is important. In practice, this means that research participants tend to be highly selected, homogenous in clinical characteristics, self-referred, and therapists are well trained and monitored for adherence to treatment manuals (Andersson \& Hedman, 2013). Moreover, efficacy studies tend to be conducted at research university clinics where therapists usually have smaller caseloads sometimes supported by students in training. In effect, it is often unclear if 
the results of such studies can be generalized to routine practice. An effectiveness study examines whether a treatment works in clinical settings and in situations that clinicians encounter in their daily routine practice (Lutz, 2003). It can be argued however that clinical intervention research and trials on psychotherapy, always have elements of effectiveness as they include real patients with disorders that are indeed both comorbid and severe (Stirman et al., 2003). The support for the efficacy of guided ICBT for mood and anxiety disorders has been covered in several systematic reviews and meta-analyses with effect sizes similar to those of regular CBT (Spek et al., 2007; Andrews et al., 2010; Hedman et al., 2012). Andersson and Hedman (2013) defines effectiveness studies as a study conducted in a setting equivalent or similar to routine clinical care where patients are not solely recruited through self-referral and treatments are delivered by staff with permanent employment. The efficacy of ICBT has been proven in a vast number of trials and the number of trials investigating the effectiveness of ICBT is increasing but is however, few in number (Andersson \& Hedman, 2013; Andersson \& Titov, 2014). The increasing number of effectiveness studies on ICBT for anxiety and mood disorders includes studies on panic disorder, social phobia, generalized anxiety disorder, posttraumatic stress disorder and depression (Hedman et al., 2013). These trials suggest that the effects found in controlled efficacy trials on guided ICBT tend to be replicated in clinical practice.

While ICBT is a promising treatment option that could be used to increase accessibility to evidence-based psychological treatment, it is of importance to investigate whether it is also effective when delivered in a routine care setting. Without effectiveness studies there is a risk of implementing new treatments that might not work in contexts outside the highly controlled randomised trials that have been conducted. As effectiveness studies on ICBT for different age groups are lacking it is important to increase the body of knowledge in this area by investigating how the treatment works in a routine care setting. From the existing effectiveness trials it is indicated that it is possible to transfer ICBT to clinical practice with sustained effects and moderate to large effect sizes (Andersson \& Hedman, 2013). In this thesis both efficacy studies (Paper I and IV) and effectiveness studies (Paper II and III) are included. 


\section{Overall aim}

The overall aim of this thesis is to further develop and test the effects of tailored internet-based cognitive behavioural therapy on the basis of age, for adolescents, young adults and older adults. Specifically by:

Developing and testing the effects of individually tailored internet-based cognitive behavioural therapy for adolescents with anxiety and comorbid depressive symptoms within a child and adolescent psychiatric clinic.

Adapting and testing the effects of individually tailored internet-based cognitive behavioural therapy for young adults and adults with panic attacks with comorbid anxiety and depressive symptoms in a randomized controlled trial.

Adapting and testing the effects of individually tailored internet-based cognitive behavioural therapy for young adults with anxiety and comorbid depressive symptoms within a Youth Health Care Centre.

Adapting and testing the effects of individually tailored internet-based cognitive behavioural therapy for older adults with anxiety and comorbid depressive symptoms in a randomized controlled trial. 


\section{Empirical studies}

\section{Paper I. Silfvernagel, K., Gren-Landell, M., Emanuelsson, M., Carlbring, P., \& Andersson, G. [2015). Individually tailored internet-based cognitive behavior therapy for adolescents with anxiety disorders: A pilot effectiveness study. Internet Interventions, 2, 297-302.}

\section{Aim}

The aim of Paper I was to develop and test the effects of individually tailored ICBT for adolescents with anxiety and comorbid depressive symptoms. The intervention was developed and tested within a child and adolescent psychiatric clinic.

\section{Methods}

In this single-group open trial, participants were recruited through ordinary referral routes (i.e. self-referral, referral through a parent/guardian/doctor) within a child and adolescent psychiatric clinic. Information about the study was given on a website hosted by the clinic, and brochures and information sessions were offered to all student counseling facilities in the area. After being referred to the trial, participants met with the project leader for an initial assessment to see if they met the inclusion criteria and to receive further information about the project. During this initial meeting written consent was obtained. Inclusion criteria for the trial required that the participant be $15-19$ years old, or turning 15 within the year of entering the trial, and seeking treatment at the clinic for mild to moderate anxiety, including: social anxiety, excessive worrying or panic attacks. Exclusion criteria were that the participant met diagnostic criteria for obsessivecompulsive disorder, post-traumatic stress disorder, severe depression, risk of suicide, suffering from a severe psychiatric disorder (i.e. bipolar disorder and psychosis), had ongoing alcohol abuse/dependence, or other social or psychological problems deemed to overshadow the anxiety problems. Participants could not be in psychological treatment and if on medication had to be on a stable dose for at least three months. Participants who met the inclusion criteria were asked to complete an online screening via the internet 
treatment platform. In addition to background questions (i.e. questions regarding the adolescents living situation, number of siblings, occupation of their parents and the family's economical situation, see Table 2), this included the Beck Anxiety Inventory (BAI; Beck et al., 1988), Clinical Outcomes in Routine Evaluation-Outcome Measure (CORE-OM; Barkham et al., 2001), Montgomery-Åsberg Depression Rating Scale-Self-Rated (MADRS-S; Svanborg \& Åsberg, 1994) and the Alcohol Use Disorders Identification Test (AUDIT; Saunders et al., 1993).

The semi-structured interview, Anxiety Disorders Interview Schedule for DSM-IV: Child and Parent Versions (ADIS-C/P; Silverman \& Albano, 1996) was administrated face-to-face to determine present diagnosis for the adolescent along with providing information for a behavior-analysis to determine treatment prescription. The adolescent was not required to meet the diagnostic threshold for an anxiety disorder on the ADIS-C/P to participate in the study. At post-treatment the same procedure was repeated with the exception of AUDIT, which was only used at screening.

Treatment consisted of tailored ICBT adapted for adolescents. The duration of treatment was 6-18 weeks with a prescription of 6-9 treatment modules for each participant. The participants were advised to spend 1-2 weeks on each prescribed module and the treatment was combined with additional telephone calls or face-to-face sessions if required. Treatment consisted of 17 potential modules, with different fictitious case examples. The language was adapted to suit the age group. The modules were derived from previous studies on tailored ICBT for anxiety and depression (Andersson et al., 2011; Carlbring et al., 2011; Johansson et al., 2012; Bergman Nordgren et al., 2014; Silfvernagel et al., 2012). All modules were based on established and evidence-based CBT principles (i.e. exposure). The modules included psychoeducation, exposure exercises, behavioral experiments and homework assignments. Two psychologists provided therapist guidance. The treatment was individually tailored for each participant based on the results of the ADIS-C/P interview. The ADIS-C/P interview provided the therapist with information for a behavioral analysis that in turn guided the therapist in choosing the modules for each adolescent. For example if the adolescent presented symptoms of social anxiety along with excessive 
worrying they could receive the modules Introduction, Cognitive restructuring 1 and 2, Social anxiety 1 and 2, Worrying and Relapse prevention.

Changes in questionnaire scores between pre- and post-treatment were evaluated using paired sample $t$-tests. The within-group effect sizes, Cohen's $d$, was calculated from the observed means and observed pooled standard deviations from pre- to post-measurement. Non-response was handled based on the principle Complete Cases (Salim, MacKinnon, Christensen \& Griffiths, 2008), which means that only data from the participants who completed the survey were included in the analysis. 
Table 2. Demographic description of the participants at pre-treatment.

\begin{tabular}{|c|c|}
\hline & Treatment group $(\mathrm{n}=11)$ \\
\hline \multicolumn{2}{|l|}{ Gender, n (\%) } \\
\hline Male & $5(45.5 \%)$ \\
\hline Female & $6(54.5 \%)$ \\
\hline \multicolumn{2}{|l|}{ Age (years) } \\
\hline Mean (SD) & $16.8(1.66)$ \\
\hline Minimum-maximum & $14-19$ \\
\hline \multicolumn{2}{|l|}{ Living situation, n (\%) } \\
\hline With mom and dad & $8(72.7 \%)$ \\
\hline With mom & $2(18.2 \%)$ \\
\hline Other & $1(9.1 \%)$ \\
\hline \multicolumn{2}{|l|}{ Siblings, n (\%) } \\
\hline Siblings & $11(100 \%)$ \\
\hline Younger siblings & $5(45.5 \%)$ \\
\hline Older siblings & $3(27.3 \%)$ \\
\hline Younger and older siblings & $3(27.3 \%)$ \\
\hline \multicolumn{2}{|l|}{ Financial family situation, $n(\%)$} \\
\hline Very good & $5(45.5 \%)$ \\
\hline Pretty good & $3(27.3 \%)$ \\
\hline Some financial difficulties & $3(27.3 \%)$ \\
\hline \multicolumn{2}{|l|}{ Employment status of parents, n (\%) } \\
\hline Both employed & $9(81.8 \%)$ \\
\hline $\begin{array}{l}\text { One on sick leave/ unemployed and one } \\
\text { employed }\end{array}$ & $2(18.2 \%)$ \\
\hline \multicolumn{2}{|l|}{ Diagnosis based on ADIS, n (\%) } \\
\hline Generalized anxiety disorder & $8(72.7 \%)$ \\
\hline Panic disorder & $4(36.4 \%)$ \\
\hline Panic disorder + agoraphobia & $1(9.1 \%)$ \\
\hline Social phobia & $7(63.6 \%)$ \\
\hline Specific phobia & $5(45.5 \%)$ \\
\hline Dysthymia & $2(18.2 \%)$ \\
\hline Comorbid disorders & $7(63.6 \%)$ \\
\hline
\end{tabular}




\section{Results and discussion}

Paired sample $t$-tests showed significant results across all outcome measures, primary and secondary, with large within-group effect sizes. At post-treatment, 5 of 8 participated in the ADIS interview. Out of these adolescents 80 percent (4/5) no longer met DSM-IV criteria for their primary anxiety disorder. Of the 11 adolescents allocated to treatment, 8 completed a mean of 6.5 modules out of 6-9 modules prescribed. Six adolescents chose to use the option with additional sessions face-to-face at the clinic and 6 adolescents asked for additional telephone-based consultations during treatment. Three of the parents asked for parental support during the treatment.

The significant effects that were found on all dependent measures immediately following treatment and adherence rates for the 8 adolescents are consistent with previous trials on CBT and ICBT for adolescents (Spence et al., 2011; Tillfors et al., 2011; Lenhard et al., 2014), and with previous trials on tailored ICBT for young adults and adults (Carlbring et al., 2011; Paper II). Overall, the results found in this study suggest that tailored ICBT may be a suitable treatment for adolescents with anxiety. Existing studies, including this study, indicate promising results but larger studies are needed. There is also limited empirical data to date that clearly indicates whether and when adolescents might require or benefit from ICBT programs designed specifically for their age group. The significant results and large within-group effect sizes reported in this study should be viewed with caution given the most important limitation of this study: the small sample size and the lack of randomization to a control group, limiting internal validity of the study. In addition, there was no follow-up of treatment results after the post-assessment. However, the study was conducted in a clinical setting with a population that is common in child and adolescent psychiatry. 


\title{
Paper II. Silfvernagel, K., Carlbring, P., Kabo, J., Edström, S., Eriksson, J., Månson, L., \& Andersson, G. (2012). Individually tailored internet-based treatment for young adults and adults with panic attacks: Randomized controlled trial. Journal of Medical Internet Research, 14 [3], e65.
}

\begin{abstract}
Aim
The aim of Paper II was to test the effects of individually tailored ICBT for young adults and adults with panic attacks with comorbid anxiety and depressive symptoms in a randomized controlled trial.
\end{abstract}

\section{Methods}

The participants were recruited via an online list among individuals who had expressed an interest in participating in research on internet-based cognitive behavior therapy for panic disorder and generalized anxiety disorder. They were presented with the project platform, which contained information about the trial, how to register, and how to submit written informed consent. Screening consisted of the following questionnaires via the internet: Montgomery-Åsberg Depression Scale-Self-rated (MADRS-S; Svanborg \& Åsberg, 1994); Clinical Outcomes in Routine Evaluation-Outcome Measure (CORE-OM; Barkham et al., 2001); Beck Anxiety Inventory (BAI; Beck, Epstein, Brown \& Steer, 1988); Quality of Life Inventory (QOLI; Frisch, Cornell, Villanueva \& Retzlaff, 1992); Alcohol Use Disorders Identification Test (AUDIT; Saunders, Aasland, Babor, de la Fuente \& Grant, 1993); and 13 additional questions with reference to demographic variables. If the participants met the initial inclusion criteria they underwent further screening consisting of the Structured Clinical Interview for DSM-IV Axis I Disorders (SCID-I; First, Spitzer, Gibbon \& Williams, 2002) and the primary outcome measure, the Panic Disorder Severity Scale (PDSS; Shear et al., 1997), conducted over the telephone by three clinical psychology MSc students who had completed their clinical training. The participants had to have reoccurring panic attacks to be included. They could also fulfill the Diagnostic and Statistical Manual of Mental Disorders, 4th edition, text revision (APA, 2000) criteria for any specific anxiety disorder, or anxiety 
disorder not otherwise specified except for obsessive-compulsive disorder and posttraumatic stress disorder, which would lead to exclusion. Participants could also meet the criteria for comorbid major depression, but not as the primary disorder. The participants had to be between the ages of 18 and 30 years or between 31 and 45 years; have a total score of $<31$ on the MADRS-S and a score $<4$ points on item 9 (suicidal thoughts) on MADRS$\mathrm{S}$; not currently be in psychotherapy; if on medication, be on stable dosage for the last 3 months; and not be at risk of alcohol abuse or fulfilling the criteria for current alcohol addiction. 149 individuals expressed an interest in the trial, which commenced in February 2010. After screening and diagnostic interview, 57 participants were included. For a demographic description of the participants, see Table 3. The participants were divided into two groups so that the two predetermined age groups 18-30 years (young adults) and 31-45 years (adults) were equally represented in each condition. The blocked randomization process was conducted through an online true random number-generation service (random.org) independent of the investigators and therapists. At post treatment participants were instructed via email to complete the follow-up questionnaires and to participate in a semi-structured telephone interview carried out by a blinded assessor who had no earlier contact with the participants. The same procedure was repeated at 12 months after treatment completion.

The treatment consisted of 19 CBT modules derived from previous ICBT trials on panic disorder (Carlbring et al., 2006), generalized anxiety disorder, social phobia (Andersson et al., 2006), depression (Vernmark et al., 2010), and tailored ICBT for anxiety and depression (Carlbring et al., 2011). In this trial the first module (introduction) and the last module (relapse prevention) were fixed, and the following 17 were optional for the therapists to prescribe: cognitive restructuring ( 2 modules); panic disorder ( 2 modules); agoraphobia (1 module); generalized anxiety (3 modules); social anxiety (2 modules); behavioral activation (2 modules); applied relaxation (1 module); stress ( 1 module); mindfulness ( 1 module); problem solving (1 module); and establish a better sleep pattern ( 1 module). The modules are all based on established and evidence-based CBT components. The panic modules, for example, consisted of psychoeducation and interoceptive exposure. All modules included psychoeducation, nearly all contained exposure exercises, 
and some contained behavioral experiments depending on the content. All modules contained homework assignments for the participants, which consisted of questions on the psychoeducational sections and tasks for the participant to complete, such as exposure exercises. The aim was to prescribe 6-8 modules within an 8-week time frame for each participant. A typical prescription for the participants could be an introduction, cognitive restructuring 1 and 2, panic disorder 1 and 2, agoraphobia, applied relaxation, and relapse prevention. Therapist guidance was included in the trial. The therapists were three clinical psychology MSc students who had completed their clinical training and who were supervised by experienced clinical psychologists (senior authors). The therapists were responsible for 9-10 participants each during the 8 weeks of treatment. The treatment was individually tailored for each participant based on the results of the SCID-I interview and the clinical impression from the telephone interview. The participants were required to have access to a computer with an Internet connection and be able to download the prescribed modules in PDF format through an encrypted contact system, which they also used when communicating with their therapist. The participants were advised to spend 1 week on each prescribed module. The therapists spent approximately 15 minutes per week with each participant (estimated). The control condition consisted of a waitlist group. Participants were informed that they would receive the treatment after 10 weeks, when the treatment group had completed their treatment.

A mixed-models approach with an unstructured covariance structure was endorsed as a way to handle missing data at post treatment and at the 1-year follow-up. As suggested by Gueorguieva and Krystal (2004), the mixedeffect models approach was used due to their advantages over traditional methods of repeated-measures analysis. The between-group and withingroup effect sizes (Cohen's $d$ ) was calculated from estimated means and observed pooled standard deviations. To examine whether the randomization process had succeeded in generating a balanced distribution across the two conditions, independent $t$-tests and a chi-square test were used for the demographic data and pre-treatment measures. 
Table 3. Demographic description of the participants at pre-treatment.

\begin{tabular}{|c|c|c|c|c|}
\hline & & $\begin{array}{l}\text { Treatment } \\
(\mathrm{n}=29)\end{array}$ & $\begin{array}{l}\text { Control } \\
(\mathrm{n}=28)\end{array}$ & $\begin{array}{l}\text { Total } \\
(\mathrm{n}=57)\end{array}$ \\
\hline \multirow[t]{2}{*}{ Gender } & Male & $8(27.6 \%)$ & $12(42.9 \%)$ & $20(35.1 \%)$ \\
\hline & Female & $21(72.4 \%)$ & $16(57.1 \%)$ & $37(64.9 \%)$ \\
\hline \multirow[t]{4}{*}{ Age } & Mean (SD) & $32.3(7.4)$ & $32.5(6.5)$ & $32.4(6.9)$ \\
\hline & Min-Max & $20-45$ & $21-44$ & $20-45$ \\
\hline & $18-30$ & $13(44.8 \%)$ & $12(42.9 \%)$ & $25(43.9 \%)$ \\
\hline & $31-45$ & $16(55.2 \%)$ & $16(57.1 \%)$ & $32(56.1 \%)$ \\
\hline \multirow[t]{5}{*}{$\begin{array}{l}\text { Highest } \\
\text { educational } \\
\text { level }\end{array}$} & $\begin{array}{l}\text { Nine year } \\
\text { compulsory } \\
\text { school }\end{array}$ & $2(6.9 \%)$ & $2(7.1 \%)$ & $4(7.0 \%)$ \\
\hline & $\begin{array}{l}\text { Secondary } \\
\text { school }\end{array}$ & $11(37.9 \%)$ & $4(14.3 \%)$ & $15(26.3 \%)$ \\
\hline & Vocational & $1(3.4 \%)$ & $3(10.7 \%)$ & $4(7.0 \%)$ \\
\hline & $\begin{array}{l}\text { College/univ } \\
\text { ersity (not } \\
\text { compl.) }\end{array}$ & $5(17.2 \%)$ & $7(25.0 \%)$ & $12(21.1 \%)$ \\
\hline & $\begin{array}{l}\text { College/univ } \\
\text { ersity } \\
\text { (compl.) }\end{array}$ & $10(34.5 \%)$ & $12(42.9 \%)$ & $22(38.6 \%)$ \\
\hline \multirow[t]{2}{*}{ Psychotherapy } & $\begin{array}{l}\text { No } \\
\text { experience }\end{array}$ & $10(34.5 \%)$ & $6(21.4 \%)$ & $16(28.1 \%)$ \\
\hline & $\begin{array}{l}\text { Previous } \\
\text { experience }\end{array}$ & $19(65.5 \%)$ & $22(78.6 \%)$ & $41(71.9 \%)$ \\
\hline \multirow{9}{*}{$\begin{array}{l}\text { Anxiolytic } \\
\text { and/or } \\
\text { antidepressant } \\
\text { medication } \\
\text { Employment } \\
\text { status }\end{array}$} & Ongoing & $15(51.7 \%)$ & $12(42.9 \%)$ & $27(47.4 \%)$ \\
\hline & Completed & $4(13.8 \%)$ & $5(17.9 \%)$ & $9(15.8 \%)$ \\
\hline & $\begin{array}{l}\text { No } \\
\text { experience }\end{array}$ & $10(34.5 \%)$ & $11(39.3 \%)$ & $21(36.8 \%)$ \\
\hline & $\begin{array}{l}\text { Self- } \\
\text { employed }\end{array}$ & $2(6.9 \%)$ & $0(0 \%)$ & $2(3.5 \%)$ \\
\hline & Employed & $14(48.3 \%)$ & $14(50.0 \%)$ & $28(49.1 \%)$ \\
\hline & Unemployed & $0(0 \%)$ & $4(14.3 \%)$ & $4(7.0 \%)$ \\
\hline & Student & $5(17.2 \%)$ & $6(21.4 \%)$ & $11(19.3 \%)$ \\
\hline & $\begin{array}{l}\text { On parental } \\
\text { leave }\end{array}$ & $4(13.8 \%)$ & $2(7.1 \%)$ & $6(10.5 \%)$ \\
\hline & Sick leave & $4(13.8 \%)$ & $2(7.1 \%)$ & $6(10.5 \%)$ \\
\hline
\end{tabular}




\begin{tabular}{cllll} 
SCID-diagnosis & $\begin{array}{l}\text { Panic } \\
\text { disorder } \\
\text { Panic } \\
\text { disorder }+ \\
\text { agoraphobia }\end{array}$ & $24(82.8 \%)$ & $23(82.1 \%)$ & $47(82.5 \%)$ \\
$\begin{array}{l}\text { Generalized } \\
\text { anxiety }\end{array}$ & $2(6.9 \%)$ & $9(32.1 \%)$ & $11(19.3 \%)$ \\
& $\begin{array}{l}\text { disorder } \\
\text { Social } \\
\text { phobia }\end{array}$ & $1(3.4 \%)$ & $8(28.6 \%)$ & $9(15.8 \%)$ \\
$\begin{array}{l}\text { Anxiety } \\
\text { disorder not } \\
\text { otherwise } \\
\text { specified } \\
\text { Major } \\
\text { depression } \\
\text { Suffering } \\
\text { from } \\
\text { comorbid } \\
\text { disorders }\end{array}$ & $1(3.4 \%)$ & $0(0 \%)$ & $1(1.8 \%)$ \\
\hline SCID $=$ Structured & $2(6.9 \%)$ & $3(10.7 \%)$ & $5(8.8 \%)$ \\
\hline Clinical Interview for DSM-IV Axis I Disorders
\end{tabular}

\section{Results and discussion}

The treatment was superior to the control condition with significant interactions on all measures. A mixed-models analysis of the immediate results of the primary outcome measure and the secondary outcome measures, showed a significant interaction and moderate to large betweengroup effect sizes were observed. Age group did not interact with treatment condition across any measure. There was, however, an interaction of time and age group for BAI. Of the 29 participants in the treatment group, 7 (24\%) completed all prescribed modules (6-8) within the 8-week treatment period. A total of 17 participants $(59 \%)$ completed 50 percent of the prescribed modules and 14 (48\%) completed 75 percent of the prescribed modules. The mean number of completed modules for the whole group was 5.0 (SD 2.6). The mean number of completed modules in the young adult group was 5.15 (SD 2.34) and the corresponding number in the adult group was 4.19 (SD 3.16). This difference was not statistically significant. At the 
1-year follow-up a mixed-models analysis showed significant time effects for the primary outcome measure and for the secondary outcome measures.

The results of this trial, with moderate to large effect sizes, are consistent with previous trials of ICBT for panic disorder (Carlbring et al., 2006) and transdiagnostic ICBT treatment for anxiety (Titov, Andrews, Johnston, Robinson \& Spence, 2010). The results of his trial, although focused on individuals with reoccurring panic attacks, are hence in line with previous trials of tailored ICBT for anxiety (Carlbring et al., 2011; Păsărelu et al., 2016). No interaction effect between age group was found; there was, however, an interaction between time and age group for the BAI. This could indicate that the young adults as a group are more likely to improve in the short time frame. The effect sizes across all measures showed a tendency for larger effects among the young adults but due to the small sample size, this requires further investigation for any conclusions to be drawn. 


\section{Paper III. Silfvernagel, K., Wassermann, C., \& Andersson, G. (accepted]. Individually tailored internet-based cognitive behavioural therapy for young adults with anxiety disorders: A pilot effectiveness study. Internet Interventions.}

\section{Aim}

The aim of Paper III was to determine whether individually tailored ICBT is a feasible approach in the treatment of anxiety symptoms and comorbid anxiety and depressive symptoms for young adults in a clinical setting.

\section{Methods}

This interventional study with a single group assignment took place in a Youth Health Care Centre in Sweden. The study was approved by the regional ethics committee in Linköping and registered at ClinicalTrials.gov (NCT01402258). Participants were recruited from the Centre via selfreferral through an early version of the online platform developed by the research group (Vlaescu, Alasjö, Miloff, Carlbring \& Andersson, 2016). The platform contained information about the trial, how to register, and how to submit written informed consent. Screening consisted of the following questionnaires via the Internet: Beck Anxiety Inventory (BAI; Beck et al., 1988) (primary outcome measure); Montgomery-Åsberg Depression ScaleSelf-rated (MADRS-S; Svanborg \& Åsberg, 1994); Clinical Outcomes in Routine Evaluation-Outcome Measure (CORE-OM; Barkham et al., 2001); Quality of Life Inventory (QOLI; Frisch, Cornell, Villanueva \& Retzlaff, 1992); Alcohol Use Disorders Identification Test (AUDIT; Saunders, Aasland, Babor, de la Fuente \& Grant, 1993); and additional questions with reference to demographic variables. If the participants met the initial inclusion criteria they underwent further screening consisting of the Structured Clinical Interview for DSM-IV Axis I Disorders (SCID-I; First, Spitzer, Gibbon \& Williams, 2002), conducted by licensed psychologists. The licensed psychologists then presented their clinical assessment to the main author and a psychiatrist before the participants were enrolled in the trial. This procedure was then repeated post treatment with the exception of AUDIT. The participants had to be between the ages of 16-25 years old, young adults, and have reoccurring anxiety symptoms to be included. They 
could also fulfill the Diagnostic and Statistical Manual of Mental Disorders, 4th edition, text revision criteria for any specific anxiety disorder, or anxiety disorder not otherwise specified. Participants could also meet the criteria for comorbid major depression, but not as the primary disorder. The participants had have a score of $<4$ points on item 9 (suicidal thoughts) on MADRS-S; not currently be in psychotherapy; and not be at risk of alcohol abuse or fulfilling the criteria for current alcohol addiction. 55 individuals expressed an interest in the trial, of which 40 filled in all the self-assessment forms. 11 were referred to child and adolescent psychiatry after this initial screening and 9 declined to participate. 20 were assessed with SCID-I, 5 individuals were referred to child and adolescent psychiatry and psychiatry and 15 participants were included the study. For a demographic description of the participants, see Table 4 .

The experimental treatment in this trial consisted of a behavioural intervention that consisted of tailored Internet-administered CBT. The treatment consisted of 22 modules with accompanying homework assignments. The modules were between 9 and 45 pages long, with an average length of 19.7 pages. The modules were derived from previous studies on tailored treatment for anxiety and depression (Carlbring et al., 2011; Silfvernagel et al., 2012). The modules were adapted for young adults both in regards to language and with clinical examples. The modules are all based on established and evidence-based CBT principles and included psychoeducation, exposure exercises, behavioural experiments and homework assignments. The treatment was individually tailored for each participant based on the results of the clinical assessment based on the questioners and the SCID-I interview. The first module (introduction) and the last module (relapse prevention) were fixed, and the following were available for the psychologist to prescribe: cognitive restructuring (2 modules); panic disorder (2 modules); panic symptoms (1 module); agoraphobia (1 module); social anxiety ( 2 modules); trauma (2 modules); setting boundaries (1 module); behavioural activation (2 modules); procrastination (1 module); worrying (1 module); generalized anxiety (3 modules); applied relaxation (1 module); and establish a better sleep pattern (1 module). Licenced and experienced psychologists provided therapist guidance and there were no automatic messages. 
Changes in questionnaire scores between pre- and post-treatment were evaluated using paired sample $t$-tests. The within-group effect sizes (Cohen's $d$ ) were calculated from the observed means and observed pooled standard deviations from pre- to post-measurement. Non-response was handled based on the principle Complete Cases (Salim et al., 2008), which means that only data from the participants who completed the survey were included in the analysis. Also examined was the percentage of participants who no longer met a diagnosis after treatment. 
Table 4. Demographic description of the participants at pre-treatment.

\begin{tabular}{|c|c|}
\hline & Treatment group $(\mathrm{n}=15)$ \\
\hline \multicolumn{2}{|l|}{ Gender, n (\%) } \\
\hline Male & $1(6.7 \%)$ \\
\hline Female & $14(93.3 \%)$ \\
\hline \multicolumn{2}{|l|}{ Age (years) } \\
\hline Mean (SD) & $21.5(1.8)$ \\
\hline Minimum-maximum & $18-24$ \\
\hline \multicolumn{2}{|l|}{ Marital status, n (\%) } \\
\hline Single & $7(46.7 \%)$ \\
\hline Living together with a partner & $6(40 \%)$ \\
\hline Living with parents & $2(13.3 \%)$ \\
\hline \multicolumn{2}{|l|}{ Highest educational level, n (\%) } \\
\hline Secondary school & $10(66.7 \%)$ \\
\hline College/university (not completed) & $5(33.3 \%)$ \\
\hline \multicolumn{2}{|l|}{ Psychotherapy, n (\%) } \\
\hline No experience & $7(46.7 \%)$ \\
\hline Previous experience & $8(53.3 \%)$ \\
\hline \multicolumn{2}{|l|}{ Anxiolytic and/or antidepressant, $\mathrm{n}(\%)$} \\
\hline Ongoing & $3(20 \%)$ \\
\hline Completed & $2(13.3 \%)$ \\
\hline No experience & $10(66.7 \%)$ \\
\hline \multicolumn{2}{|l|}{ Employment status, n (\%) } \\
\hline Employed & $6(40 \%)$ \\
\hline Unemployed & $1(6.7 \%)$ \\
\hline Student & $7(46.7 \%)$ \\
\hline Sick leave & $1(6.7 \%)$ \\
\hline \multicolumn{2}{|l|}{ SCID-I diagnosis, n (\%) } \\
\hline Generalized anxiety disorder & $4(26.7 \%)$ \\
\hline Panic disorder & $3(20 \%)$ \\
\hline Panic disorder + agoraphobia & $5(33.3 \%)$ \\
\hline Social phobia & $1(6.7 \%)$ \\
\hline Obsessive-compulsive disorder & $1(6.7 \%)$ \\
\hline Posttraumatic stress disorder & $3(20 \%)$ \\
\hline $\begin{array}{l}\text { Anxiety disorder not otherwise } \\
\text { specified }\end{array}$ & $1(6.7 \%)$ \\
\hline Major depression & $6(40 \%)$ \\
\hline
\end{tabular}




\section{Results and discussion}

Paired sample $t$-tests showed significant results across all outcome measures, primary and secondary, with large within-group effect sizes. According to the assessment of the SCID interview after treatment 7 of 10 participants no longer met the criteria for a diagnosis. Of the 15 participants who were included in the study, 9 completed all prescribed modules (8-12) with a mean of 10.1 modules. One participant announced after five of the eight planned modules that they desired to end treatment because they were feeling much improved and thereafter participated in post-measurement. The 5 who discontinued treatment prematurely finished a mean of 3.4 modules and did not participate in the post-measurement assessment.

The results of this study are consistent with study one of individually tailored ICBT conducted in a clinical setting for adolescents. The results are also in line with Halje et al. (2015) who examined CBT treatment at youth health care Centers within the same county where this study took place. The results should be viewed with caution due to a small sample size and the lack of randomization, however this was a pilot effectiveness study with experienced psychologists that conducted the interviews and administrated the treatment that strengthens the validity. An essential aspect is how well the sample in the study represents the population studied. The treatment was tested in regular care with a patient population that is common and representative for young adults seeking first-line treatment. Inclusion criteria were low with few restrictions in terms of comorbidity, which mimics a clinical population, which enhances the external validity for this study. 


\section{Paper IV. Silfvernagel, K., Westlinder, A., Andersson, S., Bergman, K., Diaz Hernandez, R., Fallhagen, L., Lundqvist, I., Masri, N., Viberg, L., Forsberg, M-L., Lind, M., Berger, T., Carlbring, P., \& Andersson, G. (submitted). Individually tailored internet-based cognitive behaviour therapy for older adults with anxiety and depression: A randomised controlled trial.}

Aim

The overall aim of Paper IV was in a randomised controlled trial to test the effects of individually tailored ICBT for anxiety and depression in order to generate an evidence-based treatment alternative that could increase access to psychological treatments for older adults. The second aim was to investigate if pre-treatment cognitive flexibility and self-perceived cognitive functioning would predict treatment outcome.

\section{Methods}

In this two-group RCT the participants were recruited via advertising in the Daily Mail. Seventy-nine individuals were assessed for eligibility and sixtysix participants were included in the trial and randomised to the two conditions individually tailored ICBT or general support from a therapist. Table 5 provides a summary of participant characteristics. The assessment consisted of the self-report questionnaires Beck Anxiety Inventory (BAI; Beck et al., 1988), Generalized Anxiety Disorder 7-item scale (GAD-7; Spitzer et al., 2006), Montgomery Åsberg Depression Rating Scale - Self Rated (MADRS-S; Svanborg \& Asberg, 1994), Patient Health Questionnaire-9 (PHQ-9; Kroenke et al., 2001), Clinical Outcomes in Routine Evaluation-Outcome Measure (CORE-OM; Evans et al., 2000), Quality of Life Inventory (QOLI; Frisch et al., 1992) and the Alcohol Use Disorders Identification Test (AUDIT; Saunders, Aasland, Babor, De la Fuente \& Grant, 1993). The Structured Clinical Interview for DSM-IV Axis I Disorders (SCID-I; First, Gibbon, Spitzer, \& Williams, 2002) was administered to establish diagnoses for the participants and to tailor the treatment. In order to investigate if pre-treatment cognitive flexibility and self-perceived cognitive functioning would predict treatment outcome an 
online in-house developed version of the standard, single-deck version of the Wisconsin Card Sorting Test-64 (WCST; Greve, 2001) featuring 64 response cards was included in the pre-treatment assessment along with the Cognitive Failure Questionnaire (CFQ; Broadbent et al., 1982) that measurers self-perceived cognitive functioning. The same procedure was then conducted at post-treatment.

The treatment group received individually tailored ICBT for symptoms of anxiety and depression while the control group received general support from a therapist. The control group was offered the same treatment after the initial trial period, that is, after the treatment group had finished the 8-week treatment. The individually tailored treatment is designed to identify participant's unique symptom profile and to provide information and skills that were likely to be helpful based on a participant's symptom profile. Individually tailored ICBT aims to tailor the treatment according to the participant's needs and symptoms with transdiagnostic components (Silfvernagel et al., 2012). The goal is to identify and target participant's specific psychosocial difficulties and psychological comorbidities with the aim of increasing the relevance, comprehensiveness and clinical outcomes of ICBT treatments. Importantly, the treatment package for older adults consists of modules derived from previous ICBT treatments (Carlbring et al., 2011; Andersson et al., 2011; Johansson et al., 2012; Silfvernagel et al., 2012; Bergman Nordgren et al., 2013), which have been adapted to make them suitable for an older population. The first module (the introduction module) and the last module (a relapse prevention module) are fixed and the following are optional for the therapists to prescribe within an 8-week timeframe: cognitive restructuring ( 2 modules), panic disorder ( 2 modules), agoraphobia ( 1 module), generalised anxiety (3 modules), social anxiety (2 modules), behavioural activation (2 modules), applied relaxation (1 module), stress (1 module), mindfulness (1 module), problem-solving (1 module) and sleep habits (1 module). There are also long and short versions for the diagnosis-specific modules for the therapist to choose from. The modules are all based on established and evidence-based CBT treatments and modules contain relevant components like psychoeducation, exposure exercises and behavioural experiments. All modules contain homework assignments for the participants, which consist of questions on the 
psychoeducational sections and tasks for the participant to complete, such as exposure exercises. Therapist guidance is included in the treatment and there are no automatic emails; either the therapist or the participant initiates all contact.

A mixed-model approach with an unstructured covariance structure was endorsed to examine treatment effects immediately after treatment for the main and secondary outcome measures with the assumption of data missing at random (MAR) for full maximum likelihood estimation (ML). With this approach an unbiased estimate of the average casual effect is obtained including all the individuals included in the trial (Hesser, 2015). Betweengroup effect sizes (Cohen's $d$ ) were calculated from estimated means and observed pooled standard deviations. To examine whether the randomization process had succeeded in generating a balanced distribution across the two conditions, independent $t$-tests were used for the demographic data and pre-treatment measures. To examine whether cognitive flexibility measured by perseverative errors on the WCST and initial levels of self-perceived cognitive functioning measured by the CFQ predicted outcome we calculated change scores and used pre-treatment scores as covariates. 
Table 5. Demographic description of the participants at pre-treatment.

\begin{tabular}{|c|c|c|c|c|}
\hline & & $\begin{array}{l}\text { Treatment } \\
\text { group } \\
(n=33)\end{array}$ & $\begin{array}{l}\text { Control } \\
\text { group } \\
(n=33)\end{array}$ & $\begin{array}{l}\text { Total } \\
(n=66)\end{array}$ \\
\hline \multirow[t]{2}{*}{ Gender } & Female & $22(66.7 \%)$ & $28(84.8 \%)$ & $50(75.8 \%)$ \\
\hline & Male & $11(33.3 \%)$ & $5(15.2 \%)$ & $16(24.2 \%)$ \\
\hline \multirow[t]{2}{*}{ Age (years) } & Mean & 66.7 & 65.5 & 66.1 \\
\hline & $\begin{array}{l}\text { Minimum- } \\
\text { maximum }\end{array}$ & $60-77$ & $60-73$ & $60-77$ \\
\hline \multirow{4}{*}{ Marital status } & Single & $11(33.3 \%)$ & $10(30.3 \%)$ & $21(31.8 \%)$ \\
\hline & $\begin{array}{l}\text { Married/ } \\
\text { living } \\
\text { together }\end{array}$ & $17(51.5 \%)$ & $18(54.5 \%)$ & $35(53 \%)$ \\
\hline & Living apart & $3(9.1 \%)$ & $3(9.1 \%)$ & $6(9.1 \%)$ \\
\hline & $\begin{array}{l}\text { Widow/ } \\
\text { widower }\end{array}$ & $2(6.1 \%)$ & $2(6.1 \%)$ & $4(6.1 \%)$ \\
\hline \multirow{4}{*}{$\begin{array}{l}\text { Highest } \\
\text { educational } \\
\text { level }\end{array}$} & $\begin{array}{l}\text { Compulsory } \\
\text { school }\end{array}$ & $4(12.1 \%)$ & $3(9.1 \%)$ & $7(10.6 \%)$ \\
\hline & $\begin{array}{l}\text { Secondary } \\
\text { school }\end{array}$ & $6(18.2 \%)$ & $8(24.2 \%)$ & $14(21.2 \%)$ \\
\hline & Vocational & $7(21.2 \%)$ & $3(9.1 \%)$ & $10(15.2 \%)$ \\
\hline & $\begin{array}{l}\text { College/ } \\
\text { university }\end{array}$ & $16(48.5 \%)$ & $19(57.6 \%)$ & $35(53 \%)$ \\
\hline \multirow{4}{*}{$\begin{array}{l}\text { Employment } \\
\text { status }\end{array}$} & Retired & $26(78.8 \%)$ & $22(66.7 \%)$ & $48(72.7 \%)$ \\
\hline & Employed & $3(9.1 \%)$ & $10(30.3 \%)$ & $13(19.7 \%)$ \\
\hline & Sick leave & $1(3.0 \%)$ & $0(0 \%)$ & $1(1.5 \%)$ \\
\hline & Unemployed & $3(9.1 \%)$ & $1(3.0 \%)$ & $4(6.1 \%)$ \\
\hline $\begin{array}{l}\text { Psycho- } \\
\text { therapy }\end{array}$ & No experience & $8(24.2 \%)$ & $13(46 \%)$ & $21(34.6 \%)$ \\
\hline Anxiolytic & On-going & $15(45.5 \%)$ & $14(42.4 \%)$ & $29(43.9 \%)$ \\
\hline and/or & Completed & $12(36.4 \%)$ & $10(30.3 \%)$ & $22(33.3 \%)$ \\
\hline $\begin{array}{l}\text { antidepressant } \\
\text { medication }\end{array}$ & No experience & $6(18.2 \%)$ & $9(27.3 \%)$ & $15(22.7 \%)$ \\
\hline $\begin{array}{l}\text { Somatic } \\
\text { illness }\end{array}$ & Self-reported & $19(57.6 \%)$ & $18(54.5 \%)$ & $37(56.1 \%)$ \\
\hline $\begin{array}{l}\text { Medication } \\
\text { for somatic } \\
\text { illness }\end{array}$ & On-going & $17(51.5 \%)$ & $18(54.5 \%)$ & $35(53 \%)$ \\
\hline
\end{tabular}




\begin{tabular}{lllll}
$\begin{array}{l}\text { Psychiatric } \\
\text { diagnosis }\end{array}$ & $\begin{array}{l}\text { Generalized } \\
\text { anxiety } \\
\text { disorder }\end{array}$ & $19(57.6 \%)$ & $16(48.5 \%)$ & $35(53 \%)$ \\
& $\begin{array}{l}\text { Panic disorder } \\
\text { Panic disorder }\end{array}$ & $5(15.2 \%)$ & $6(18.2 \%)$ & $11(16.7 \%)$ \\
& $\begin{array}{l}\text { with } \\
\text { agoraphobia }\end{array}$ & $0(0 \%)$ & $4(6.1 \%)$ \\
& $\begin{array}{l}\text { Social phobia } \\
\text { Posttraumatic } \\
\text { stress disorder }\end{array}$ & $2(12.1 \%)$ & $2(6.1 \%)$ & $6(9.1 \%)$ \\
& $\begin{array}{l}\text { Major } \\
\text { depression }\end{array}$ & $13(39.4 \%)$ & $8(24.2 \%)$ & $21(31.8 \%)$ \\
\hline
\end{tabular}

\section{Results and discussion}

The mixed-model analysis of the immediate results of the primary outcome measure of anxiety showed a significant interaction effect. For the secondary outcome measures of anxiety, depression and quality of life, significant interaction effects were observed with moderate to large between-group effect sizes with the exception of quality of life wehre a small between-group effect size was observed. Of the 33 participants randomised to tailored internet based cognitive behaviour therapy, 11 (33 $\%$ ) completed all prescribed modules within the treatment period, 18 (55\%) completed 75 per cent of the prescribed modules and $22(67 \%)$ completed 50 per cent of the prescribed modules. A subsample of the 33 participants allocated to the treatment group $(\mathrm{n}=19)$ completed a 1-year follow-up. On the primary outcome measure BAI, a score of 10.37 ( $\mathrm{SD}=6.83)$ was obtained, suggesting that improvements were sustained (within-group Cohen's $d=0.80$ ). Similar effects were found for the GAD-7, PHQ-9, MADRS-S, CORE-OM and QOLI, with within-group effect sizes ranging from $d=0.63$ to 1.13 . There were significant partial correlations between pre-treatment scores on the WCST perseverative errors and change scores on the main outcome BAI ( $r=-.45, p=.05, \mathrm{n}=20)$, and on CORE-OM, MADRS-S, QOLI, PHQ-9 and GAD-7. There were no significant partial correlations for the BAI $(r=.20, p=.38, \mathrm{n}=22)$, CORE-OM, MADRS-S, QOLI, PHQ-9 or GAD-7 when a similar analysis was conducted on the selfreported CFQ. 
The results of this study are consistent with several clinical trials on internet-based cognitive behavior therapy for older adults (Dear et al., 2013; Dear et al., 2015a, b; Titov et al., 2015; Zou et al., 2012) and represents one potential approach for increasing access to treatment for the age group.

To date, while consistent results have been obtained across trials, all of the research on ICBT programs specifically designed for older adults has been conducted by a limited number of research groups and the clinical trials have involved relatively small numbers of participants. Alongside this, there is also a need for studies examining the implementation of ICBT for older adults into routine practice, particularly where participants are referred to ICBT treatment rather than seeking ICBT as is often the case in clinical trials. 


\section{General discussion}

\section{Main findings and conclusions}

The aims of this thesis were to further develop and test the effects of tailored internet-based cognitive behavioural therapy on the basis of age, for adolescents, young adults and older adults. Specifically by developing and testing the effects of individually tailored internet-based cognitive behavioural therapy for adolescents with anxiety and comorbid depressive symptoms and by adapting and testing the effects of individually tailored internet-based cognitive behavioural therapy for young adults and older adults with anxiety and comorbid depressive symptoms. These aims were tested in two pilot effectiveness studies and two efficacy randomised controlled trials. In these trials modules from previous trials on tailored ICBT (Carlbring et al., 2011; Johansson et al., 2012; Bergman Nordgren et al., 2014) were adapted for the different age groups both in regards to language and with clinical examples, with different fictitious case examples but sharing the same interventions. The modules are all based on established and evidence-based CBT interventions and modules contain relevant components like psychoeducation, exposure exercises and behavioural experiments. The treatment can be considered empirically driven rather than theory driven; with modules origin from diagnose specific ICBT protocols on panic disorder (Carlbring et al., 2006), generalized anxiety disorder, social phobia (Andersson et al., 2006) and depression (Vernmark et al., 2010).

Based on the results from the first (Paper I) and second (Paper III) pilot effectiveness trial a tentative conclusion is that online materials based on CBT could be useful along with standard treatment delivered in child and adolescent psychiatric clinics and in youth care. These are the first ICBT studies of its kind using an adolescent and youth sample in a clinical setting in Sweden. The significant effects that were found on all dependent measures immediately following treatment and adherence rates for the adolescents are consistent with previous trials on CBT and ICBT for adolescents and slightly higher than adherence rates for young adults. 
As was shown in Paper II, significant treatment effects were found for all dependent measures immediately following treatment, and significant time effects at the 12-month follow-up, showing that a majority of the participants remained stable after completing their treatment which indicates that tailoring an internet-based treatment can be a feasible approach in the treatment of panic symptoms and comorbid anxiety and depressive symptoms. The results indicate that younger adults benefit from treatment as much as adults between 30 and 45 years of age. The prevalence of untreated anxiety and depression represents a critical public health issue in the different age groups, and the proportion of older adults is set to grow over the coming decades. Adolescents, young adults and older adults have until recently been overlooked in global health and social policy, one reason why they have had fewer health gains with economic development than other age groups. Studies in adults suggest that most mental disorders begin before 25 years of age, most often between 11 and 18 years (Patton et al., 2016). Recent prospective studies have found that while mental health problems are very common during adolescence, not all persist into adulthood, particularly if the episodes are brief. These understandings have put a growing emphasis on early clinical interventions through more accessible and better resourced primary health care through youth focused mental health services (Halje et al., 2015). Online and mobile-phone interventions could play a positive part in prevention and promotion of access to clinical services since despite their clinical efficacy; there are numerous barriers to traditional face-to-face psychological treatments. Internet-based ICBT represents one potential approach for increasing access to treatment and several clinical trials have now been conducted with encouraging results (i.e. Hedman et al., 2012).

The findings of Paper IV, the first of its kind in Sweden, indicate that tailored ICBT is beneficial for older adults age 60 and above, and previous trials in Australia and Canada indicate that ICBT is acceptable to older adults and can result in clinically significant reductions in levels of anxiety and depression. In this paper, significant partial correlation between perseverative errors on the WCST and change scores on the included outcome measures was found. Further studies using WCST when testing 
ICBT for older adults is needed to consolidate the predicting findings in this study that are preliminary and based on a small sample.

\section{Limitations}

There are limitations to this thesis. In regards to Paper I, the significant results and large within-group effect sizes reported in this study should be viewed with caution given the most important limitation of this study: the small sample size and the lack of randomization to a control group, limiting the internal validity of the study. In addition, there was no follow-up of treatment results after the post-assessment. However, the study was conducted in a clinical setting with a population that is common in child and adolescent psychiatry. Inclusion criteria were inclusive, with few restrictions with regards to comorbidity, thus strengthening the external validity. This means that the results are interesting from the standpoint of generalizability, and further studies ought to be conducted with larger samples. Tailored ICBT seems to be a way to reach adolescents who had not entered psychological treatment before and ICBT may be useful in reaching adolescents reluctant to attending the clinic for treatment. In Paper II the prescription of treatment modules in the study may be unreliable because it was based on a structured diagnostic procedure (SCID-I) and clinical impression by relatively inexperienced clinicians. A more comprehensive clinical assessment, such as a functional analysis, may have resulted in the prescription of other modules. Also worth mentioning is that the treatment modules consisted of modules derived from diagnosis-specific trials and were mainly structured after each diagnosis (i.e. panic disorder and not panic symptoms). This was addressed in the other trials (Paper I, II and IV), the modules were made symptom specific and less difficult, and less specific for particular diagnoses. Second, the use of a waitlist control condition is a limitation of Paper II. The use of a passive control group means that the effect of nonspecific factors cannot be determined. The lack of a comparison group at the 12-month follow-up makes it difficult to conclude that the improvements over the follow-up period were due only to the effects of the individually tailored treatment. Another limitation is the size of the study, which in turn affects the generalizability of the results. Another limitation is that the participants in this study had expressed an 
interest in ICBT for their problems and therefore the participants may have been highly motivated to undergo treatment. However, we did not measure how highly motivated the participants were. A final limitation of this study was its inability to detect age differences, and it is possible that small but clinically meaningful differences would have been detected with a larger sample. The results of Paper III are in line with Halje et al. (2015) who examined CBT treatment at Youth Health Care Centers within the same county where this study took place. The results should be viewed with caution due to a small sample size and the lack of randomization, however this was a pilot effectiveness study with experienced psychologists conducting the interviews and administrating the treatment, which strengthens the validity. The use of standardized diagnostic interviews is not common practice at Youth Health Care Centers in the county (Halje et al., 2015). In Paper IV, the sample was small. There was not a pure waitlist control group and the control group was provided with support, with the role of support unclear. In the field of depression, supportive non-directive therapy has been found to have positive effects (Cuijpers et al., 2012). This may however also be regarded as a strength of the study as it is well established that psychological treatment, including ICBT, is better than just waiting (Cuijpers \& Cristea, 2016). Second, the treatment approach involved selecting treatment modules based on symptoms and preferences and the reliability of the selection procedure is not established. Preliminary work implies that clients may be able to take more responsibility for the selection of treatment modules (Andersson et al., 2011), but it could also be the case that some components like exposure are more easily avoided. Overall it is a limitation that it is unclear which modules are driving effects, and also a problem with measures as transdiagnostic and tailored approaches would benefit from tailored assessments. The sample was recruited via mass media and even if this particular study had a lower proportion of participants with university education than we usually see (about half as compared to two thirds in many previous studies), it is still the case that we cannot infer that this treatment would work under regular clinical conditions. On the other hand ICBT for adults has been found to work in effectiveness studies (Andersson \& Hedman, 2013), and in the study by Mewton et al. (2013) this appeared to be the case for older adults as well. One limitation that all the trials have are the measurements used to measure 
anxiety and depression. The measurements are general measures of anxiety and does not target specific anxiety disorders. The measurements are also not adapted for the different age groups in general with the exception of CATS, although some are validated for the age group. In the future it is recommended to include age and diagnostic specific measurements.

\section{Future Directions}

Despite the positive findings of the studies in this thesis, there is a need for more research examining the acceptability and effectiveness of ICBT for adolescents, young adults and older adults with anxiety and depression. While consistent results have been obtained across these trials, all of the research on tailored ICBT has been conducted by one research group and the trials have involved relatively small numbers of participants. There is, therefore, a strong need for independent replication by other research groups, and the implementation and evaluation of larger trials involving much larger numbers of participants to establish the robustness of observed clinical effects. Alongside this, there is also a need for studies examining the implementation of tailored ICBT for different age groups into routine practice, particularly where participants are referred to ICBT treatment rather than seeking ICBT. It would be interesting to see if a briefer version of ICBT, including psychoeducational components, could increase motivation to seek face-to-face CBT and reduce risks of possible negative effects in digital distributed treatments (Rozental et al., 2014). Another suggestion would be to use an internet platform for homework assignments as part of regular CBT (Månsson et al., 2013), in other words, blending face-to-face and internet components. Moreover, given the smaller number of participants in existing trials, there has not been the ability to examine whether the various age cohorts of age groups differ in terms of how acceptable they find tailored ICBT or how they respond to tailored ICBT. Related to this issue, there are limited empirical data to clearly indicate whether, and if so when, different age groups might require or might benefit from ICBT programs designed specifically for them (i.e. providing ageappropriate examples), that is, compared with programs designed generally for adults with anxiety and depression. The degree to which internet-based treatments need to be modified for different age groups holds important 
implications for the implementation of ICBT into routine care. Before the implementation on a larger scale of internet-based cognitive behavioural therapy in primary care and psychiatric settings for adolescents, young adults and older adults more effectiveness trials are highly recommended. The process of tailoring the treatment is also an area that can be examined further, perhaps sophisticated algorithms can be explored for the tailoring process. Results comparing tailored ICBT with transdiagnostic ICBT indicates that the treatments have similar effects (Păsărelu et al., 2016) and it would be interesting to directly compare the different treatment formats. Other aspects such as mechanisms of change and predictors for tailored ICBT need to be explored further.

Consequently, there is a significant opportunity and considerable benefit in future research exploring tailored ICBT for treating anxiety in different age groups across the life span. 


\section{References}

American Psychiatric Association. (2000). Diagnostic and statistical manual of mental disorders. (4th ed., text revision). Washington, DC: Author.

American Psychiatric Association. (2013). Diagnostic and statistical manual of mental disorders: DSM-5. Arlington: American Psychiatric Association.

Andersson G. (2009). Using the Internet to provide cognitive behaviour therapy. Behaviour Research and Therapy, 47, 175-80. http://dx.doi.org/10.1016/j.brat.2009.01.010

Andersson, G., Carlbring, P., Holmström, A., Sparthan, E., Furmark, T., Nilsson-Ihrfelt, E., Buhrman, M., \& Ekselius, L. (2006). Internet-based self-help with therapist feedback and in vivo group exposure for social phobia: a randomized controlled trial. Journal of Consulting and Clinical Psychology, 74(4), 677-686. doi: 10.1037/0022-006X.74.4.677

Andersson, G., \& Cuijpers, P. (2009). Internet-based and other computerized psychological treatments for adult depression: a meta-analysis. Cognitive Behavior Therapy, 38 (4), 196-205. doi: 10.1080/16506070903318960

Andersson, G., Estling, F., Jakobsson, E., Cuijpers, P., \& Carlbring, P. (2011). Can the patient decide which modules to endorse? An open trial of tailored Internet treatment of anxiety disorders. Cognitive Behaviour Therapy, 40, 57-64. doi: 10.1080/16506073.2010.529457

Andersson, G., \& Hedman, E. (2013). Effectiveness of guided Internetdelivered cognitive behaviour therapy in regular clinical settings. Verhaltenstherapie, 23, 140-148. doi: $10.1159 / 000354779$

Andersson, G., \& Titov, N. (2014). Advantages and limitations of Internetbased interventions for common mental disorders. World Psychiatry, 13, 4-11. doi: 10.1002/wps.20083 
Andrews, G., Cuijpers, P., Craske, MG., McEvoy, P., \& Titov, N. (2010). Computer Therapy for the Anxiety and Depressive Disorders Is Effective, Acceptable and Practical Health Care: A MetaAnalysis. PLoS ONE 5(10): e13196. doi:10.1371/journal.pone.0013196

Barkham, M., Margison, F., Leach, C., Lucock, M., Mellor-Clark, J., Evans, C., Benson, L., Connell, J., Audin, K., \& McGrath, G. (2001). Service profiling and outcomes benchmarking using the CORE-OM: toward practice-based evidence in the psychological therapies. Clinical outcomes in routine evaluation-outcome measures. Journal of Consulting and Clinical Psychology, 69 (2), 184-196. http://dx.doi.org/10.1037/0022-006X.69.2.184.

Barlow, D.H. (2004) Psychological treatments. American Psychologist, 59, 869-878. doi: 10.1037/0003-066X.59.9.869

Barlow, D.H. (2014). Clinical handbook of psychological disorders : a step-by-step treatment manual. New York: The Guilford Press.

Beck, A. T., \& Clark, D. A. (1997). An information processing model of anxiety: Automatic and strategic processes. Behaviour Research and Therapy, 35(1), 49-58.

Beck, A. T., \& Haigh, E. A. (2014). Advances in cognitive theory and therapy: The generic cognitive model. Annual Review of Clinical Psychology, 10, 1-24. doi:10.1146/annurev-clinpsy-032813-153734

Beck, A.T., Epstein, N., Brown, G., \& Steer, R.A. (1988). An inventory for measuring clinical anxiety: psychometric properties. Journal of Consulting and Clinical Psychology, 56 (6), 893-897. http:// dx.doi.org/10.1037/0022-006X.56.6.893.

Bergman Nordgren, L., Hedman, E., Etienne, J., Bodin, J., Kadowaki, Å., Eriksson, S., Lindkvist, E., Andersson, G., \& Carlbring, P. (2014). Effectiveness and cost-effectiveness of individually tailored Internet-delivered cognitive behavior therapy for anxiety disorders in a primary care population: A randomized controlled trial. Behaviour Research and Therapy, 59, 1-11. http://dx.doi.org/10.1016/j.brat.2014.05.007. 
Boettcher, J., Carlbring, P., Renneberg, B., \& Berger, T. (2013). Internetbased interventions for social anxiety disorder - an overview. Verhaltenstherapie, 23, 160-169. doi: 10.1159/000354747

Bohlmeijer, E., Smit, F., \& Cuijpers, P. (2003). Effects of reminiscence and life review on late-life depression: a meta-analysis.

International Journal of Geriatric Psychiatry, 18, 1088-1094. doi: $10.1002 /$ gps.1018

Bower, E. S., Wetherell, J. L., Mon, T., \& Lenze, E. J. (2015). Treating Anxiety Disorders in Older Adults: Current Treatments and Future Directions. Harvard Review of Psychiatry, 23(5), 329342. doi: 10.1097/HRP.0000000000000064

Braam, AW., Prince, MJ., Beekman, AT., Delespaul, P., Dewey, ME., Geerlings, SW., Kivela, SL., Lawlor, BA., Magnusson, H., Meller, I., Pérès, K., Reischies, FM., Roelands, M., Schoevers, RA., Saz, P., Skoog, I., Turrina, C., Versporten, A., Copelan. JR. (2005). Physical health and depressive symptoms in older Europeans. British Journal of Psychiatry, 187, 35-42. doi: 10.1192/bjp.187.1.35

Brenes, GA., Penninx, BW., Judd, PH., Rockwell, E., Sewell, DD., Wetherell, JL. (2008). Anxiety, depression and disability across the lifespan. Aging \& Mental Health, 12, 158-163. doi: $10.1080 / 13607860601124115$

Britt, HC., Harrison, CM., Miller, GC., Knox, SA. (2008). Prevalence and patterns of multimorbidity in Australia. Medical Journal of Australia, 189, 72-77.

Broadbent, D., Cooper, P. F., Fitzgerald, P., \& Parkes, K. R. (1982). The cognitive failures questionnaire and its correlates. British Journal of Clinical Psychology, 21, 1-16. doi: 10.1111/j.2044-8260.1982.tb01421.x

Carlbring, P., Bohman, S., Brunt, S., Buhrman, M., Westling, BE., Ekselius, L., \& Andersson, G. (2006). Remote treatment of panic disorder: a randomized trial of internet-based cognitive behavior therapy supplemented with telephone calls. American Journal of Psychiatry, 163(12), 2119-2125. doi: 10.1176/appi.ajp.163.12.2119 
Carlbring, P., Westling, B., Ljungstrand, P., Ekselius, L., \& Andersson, G. (2001).Treatment of panic disorder via the Internet: a randomized trial of a self-help program. Behaviour Research and Therapy, 32(4), 751-764. doi: 10.1016/S00057894(01)80019-8

Carlbring, P., Maurin, L., Törngren, C., Linna, E., Eriksson, T., Sparthan, E., Strååt, M., Marquez von Hage, C., Bergman-Nordgren, L., \& Andersson, G., 2011. Individually tailored internet-based treatment for anxiety disorders: a randomized controlled trial. Behaviuor Research and Therapy 49, 18-24. http://dx.doi.org/10.1016/j.brat.2010.10.002.

Costello, E.J., Egger, H., \& Angold, A. (2003). Developmental epidemiology of anxiety disorders. In T.H.Ollendick, \& J.S. March (Eds), Phobic and anxiety disorders in children and adolescents, New York: Oxford University Press.

Cuijpers, P., \& Cristea, I. A. (2016). How to prove that your therapy is effective, even when it is not: A guideline. Epidemiology and Psychiatric Sciences, 25(5), 428-435. doi: $10.1017 / \mathrm{S} 2045796015000864$

Cuijpers, P., Driessen, E., Hollon, S. D., van Oppen, P., Barth, J., \& Andersson, G. (2012). The efficacy of non-directive supportive therapy for adult depression: A meta-analysis Clinical Psychology Review, 32, 280-291. doi: 10.1016/j.cpr.2012.01.003

Cuijpers, P., van Straten, A., \& Warmerdam, L. (2007). Problem solving therapies for depression: a meta-analysis. European Psychiatry, 22, 9-15. doi: 10.1016/j.eurpsy.2006.11.001

Day, V., McGrath, P.J., \& Wojtowicz, M. (2013). Internet-based guided self-help for university students with anxiety, depression and stress: A randomized controlled clinical trial. Behaviour Research and Therapy, 51(7), 344-351.

doi:10.1016/j.brat.2013.03.003 
Dear, BF., Staples, LG., Terides, MD., Fogliati, VJ., Sheehan, J., Johnston, L., Kayrouz. R., Dear, R., McEvoy, PM., \& Titov, N. (2016). Transdiagnostic versus disorder-specific and clinician-guided versus self-guided internet-delivered treatment for Social Anxiety Disorder and comorbid disorders: A randomized controlled trial. Journal of Anxiety Disorders, 42, 30-44. doi: 10.1016/j.janxdis.2015.08.002

Dear, BF., Zou, J., Ali, S., Lorian, C., Johnston, L., Sheehan, J., Staples, LG., Gandy, M., Fogliati, V., Klein, B., \& Titov, N. (2015a). Clinical and cost-effectiveness of clinician-guided internetdelivered cognitive behaviour therapy program for older adults with symptoms of anxiety: a randomised controlled trial.

Behavior Therapy, 46, 206-217.

doi:10.1016/j.beth.2014.09.007

Dear, BF., Zou, J., Ali, S., Lorian, C., Johnston, L., Terides, MD., Staples, LG., Gandy, M., Fogliati, V., Klein, B., \& Titov, N. (2015b). Examining self-guided internet-delivered cognitive behaviour therapy for older adults with symptoms of anxiety and depression: Two feasibility open trials. Internet Interventions, 2, 17-23. http://dx.doi.org/10.1016/j.invent.2014.11.002

Dear, BF., Zou, JB., Titov, N., Lorian, C., Johnston, L., Spence, J., Anderson, T., Sachdev, P., Brodaty, H., \& Knight, RG. (2013). Internet-delivered cognitive behavioural therapy for depression: a feasibility open trial for older adults. Australian \& New Zealand Journal of Psychiatry, 47, 169-176. doi: $10.1177 / 0004867412466154$

Diefenbach, G. J., Stanley, M. A., \& Beck, J. G. (2001). Worry content reported by older adults with and without generalized anxiety disorder. Aging and Mental Health, 5(3), 269-274. doi:10.1080/13607860120065069

DiMatteo, RM., Lepper, HS., Croghan, TW. (2000). Depression is a risk factor for noncompliance With medical treatment: metaanalysis of the effects of anxiety and depression on patient adherence. Archives of Internal Medicine, 160, 2101-2107. doi:10.1001/archinte.160.14.2101 
First, M B., Spitzer, R L, Gibbon, M., \&, Williams, J. Structured Clinical Interview for DSM-IV-TR Axis I Disorders, Research Version, Patient Edition. (SCID-I/P). New York: Biometrics Research, New York State Psychiatric Institute, November

Fogliati, VJ., Dear, BF, Staples, LG., Terides, MD, Sheehan, J., Johnston, L., Kayrouz, R., Dear, R., McEvoy, PM., \& Titov, N. (2016). Disorder-specific versus transdiagnostic and clinician-guided versus self-guided internet-delivered treatment for panic disorder and comorbid disorders: A randomized controlled trial. Journal of Anxiety Disorders, 39, 88-102. doi: 10.1016/j.janxdis.2016.03.005.

Frisch, MB., Cornell, J., Villanueva, M., Retzlaff, PJ. (1992). Clinical validation of the quality of life inventory: a measure of life satisfaction for use in treatment planning and outcome assessment. Psychological Assessment, 4(1), 92-101. doi: 10.1037/1040-3590.4.1.92

Grek, A. (2007). Clinical management of suicidality in the elderly: an opportunity for involvement in the lives of older patients. Canadian Journal of Psychiatry, 52(6 Suppl 1), 47-57.

Greve, K. W. (2001). The WCST-64: a standardized short-form of the Wisconsin Card Sorting Test. Clinical Neuropsychologist, 15(2), 228-234. doi:10.1076/clin.15.2.228.1901

Gueorguieva R, Krystal JH. (2004). Move over ANOVA: progress in analyzing repeated-measures data and its reflection in papers published in the Archives of General Psychiatry. Archives of General Psychiatry, 61(3), 310-317. doi:

10.1001/archpsyc.61.3.3102002.

Halje, K., Timpka, T., Tylestedt, P., Adler, A-K., Fröberg, L., Schyman, T., Johansson., \& Dahl, K. (2015). Self-referral psychological treatment centre for young adults: a 2- year observational evaluation of routine practice before and after treatment. $B M J$ Open, 5:e008030. doi:10.1136/bmjopen-2015-008030 
Hedman,E., Ljótsson, B., \& Lindefors, N. (2012). Cognitive behavior therapy via the Internet: a systematic review of applications, clinical efficacy and cost-effectiveness, Expert Review of Pharmacoeconomics \& Outcomes Research, 12:6, 745-764, doi: 10.1586/erp.12.67

Hesser, H. (2015). Modeling individual differences in randomized experiments using growth models: Recommendations for design, statistical analysis and reporting of results of internet interventions. Internet Interventions, 2, 110-120. doi:10.1016/j.invent.2015.02.003

Hippisley-Cox, J., Fielding, K., \& Pringle, M. (1998). Depression as a risk factor for ischaemic heart disease in men: population based case-control study. British Medical Journal, 316, 1714-1719,

Hudson, J.L., Rapee, R.M., Deveney, C., Schniering, C.A., Lyneham, H.J., Bovopoulos, N., (2009). Cognitive behavioral treatment versus an active control for children and adolescents with anxiety disorders: a randomized trial. Journal of the American Acadamy of Child and Adolescent Psychiatry, 48, 533-544. http://dx.doi.org/10.1097/CHI.0b013e31819c2401.

James, A.C., James, G., Cowdrey, F.A., Soler, A., Choke, A., (2015). Cognitive behavioural therapy for anxiety disorders in children and adolescents. Cochrane Database of Systematic Reviews, 3(6), CD004690. http://dx.doi.org/10.1002/14651858.CD004690.pub3.

Johansson, R., Sjöberg, E., Sjögren, M., Johnsson, E., Carlbring, P., Andersson, T., Rousseau, A., Andersson, G., (2012). Tailored vs. standardized Internet-based cognitive behavior therapy for depression and comorbid symptoms: a randomized controlled trial. PLoS ONE 7 (5), e36905. http://dx.doi.org/10.1371/journal.pone.0036905.

Jones, S. L., Hadjistavropoulos, H. D., \& Soucy, J. N. (2016). A randomized controlled trial of guided internet-delivered cognitive behaviour therapy for older adults with generalized anxiety. Journal of Anxiety Disorders, 37, 1-9. doi:10.1016/j.janxdis.2015.10.006 
Katon, W., \& Ciechanowski, P. (2002). Impact of major depression on chronic medical illness. Journal of Psychosomatic Research, $53,859-863$.

Kendall, P. C., (1994). Treating anxiety disorders in children: results of a randomized clinical trial. Journal of Consulting and Clinical Psychology, 62, 100-110. http://dx.doi.org/10.1037/0022006X.62.1.100.

Kendall, P. C., Gosch, E., Furr JM., \& Sood, E. (2008). Flexibility within fidelity. Journal of the American Acadamy of Child and Adolescent Psychiatry, 47, 987-993. doi: 10.1097/CHI.0b013e31817eed2f

Kendall, P. C., \& Peterman, J. S. (2015). CBT for adolescents with anxiety: mature yet still developing. American Journal of Psychiatry, 172, 519-530; doi: 10.1176/appi.ajp.2015.14081061

Kendall, P. C., \& Suveg, C. (2006) Treating Anxiety Disorders in Youth. In P. Kendall (Ed.), Child and adolescent therapy: Cognitivebehavioral procedures ( $3^{\text {rd }}$ ed., pp 243-294). New York: Guilford Press.

Kessler, R. C., Berglund, P., Demler, O., Jin, R., Merikangas, K. R., \& Walters, E. E. (2005). Lifetime prevalence and age-of-onset distributions of DSM-IV disorders in the national comorbidity survey replication. Archives of General Psychiatry, 62(6), 593602. doi:10.1001/archpsyc.62.6.593

Klein, B., Richards, JC., \& Austin, DW. (2006). Efficacy of internet therapy for panic disorder. Journal of Behavior Therapy and Experimental Psychiatry, 37(3), 213-238. doi: 10.1016/j.jbtep.2005.07.001

Kovacs, M., \& Devlin, B. (1998). Internalizing disorders in childhood. Journal of Child Psychology and Psychiatry and Allied Disciplines, 39, 47-63.

Kroenke, K., Spitzer, R. L., \& Williams, J. B. (2001). The PHQ-9: validity of a brief depression severity measure. Journal of General Internal Medicine, 16, 606-613. doi: 10.1046/j.15251497.2001.016009606.x 
Laidlaw, K., \& McAlpine, S. (2008). Cognitive behaviour therapy: How is it different with older people? Journal of Rational-Emotive \& Cognitive-Behavior Therapy, 26(4), 250-262. doi: 10.1007/s10942-008-0085-6

Law, J., Laidlaw, K., \& Peck, D. (2010). Is depression viewed as an inevitable consequence of age? The "Understandability phenomenon" in older people. Clinical Gerontologist, 33, 194209. doi:10.1080/07317111003773627

Landreville, P., Gosselin, P., Grenier, S., Hudon, C., \& Lorrain, D. (2016). Guided self-help for generalized anxiety disorder in older adults. Aging and Mental Health, 20(10), 1070-1083. doi:10.1080/13607863.2015.1060945

Lange, A., Rietdijk, D., Hudcovicova, M., van de Ven, JP., Schrieken, B., Emmelkamp, PM. (2003). Interapy: a controlled randomized trial of the standardized treatment of posttraumatic stress through the internet. Journal of Consulting and Clinical Psychology, 71(5), 901-909. doi: 10.1037/0022-006X.71.5.901

Lenhard, F., Vigerland, S., Andersson, E., Rück, C., Mataix-Cols, D., Thulin, U., Ljótsson, B., \& Serlachius, E., (2014). Internetdelivered cognitive behavior therapy for adolescents with obsessive-compulsive disorder: an open trial. PLoS One 9 (6), e100773. http://dx.doi.org/10.1371/journal.pone.0100773.

Lenze, E. J., \& Wetherell, J. L. (2009). Bringing the bedside to the bench, and then to the community: a prospectus for intervention research in late life anxiety disorders. International Journal of Geriatric Psychiatry, 24(1), 1-14. doi: 10.1002/gps.2074.

Luppa, M., Sikorski, C., Luck, T., Ehreke, L., Konnopka, A., Wiese, B., Weyerer, S., König, HH., \& Riedel-Heller, SG. (2012). Ageand gender-specific prevalence of depression in latest-life: systematic review and meta-analysis. Journal of Affective Disorders, 136, 212-221. doi: 10.1016/j.jad.2010.11.033.

Lutz, W. (2003). Efficacy, Effectiveness, and expected treatment response in psychotherapy. Journal of Clinical Psychology, 59(7), 745750. doi: $10.1002 /$ jclp.10169 
Mewton, L., Sachdev, P. S., \& Andrews, G. (2013). A naturalistic study of the acceptability and effectiveness of internet-delivered cognitive behavioural therapy for psychiatric disorders in older australians. PLoS One, 8, e 71825 . doi:10.1371/journal.pone.0071825

Månsson, K.N.T., Ruiz, E., Gervind, E., Dahlin, M., Andersson, G. (2013). Development and initial evaluation of an Internet-based support system for face to face cognitive behavior therapy: a proof of concept study. Journal of Medical Internet Research, 15, e280. http://dx.doi.org/10.2196/jmir.3031.

O'Connor, DW. (2006). Do older Australians truly have low rates of anxiety and depression?: a critique of the 1997 National Survey of Mental Health and Wellbeing. Australian \& New Zealand Journal of Psychiatry, 40, 623-631. doi: 10.1080/j.14401614.2006.01861.x

Oeppen, J., \& Vaupel, JW. (2002). Broken limits to life expectancy. Science, 296, 1029-2031. doi: 10.1126/science.1069675

Ollendick, TH. \& Hovey, LD. (2009) Competencies for treating phobic and anxiety disorders in children and adolescents. In: Thomas, J. \& Hersen, M., editors. Handbook of clinical psychology competencies. New York: Springer Verlag.

Păsărelu, C. R., Andersson, G., Bergman Nordgren, L., \& Dobrean, A. (2016). Internet-delivered transdiagnostic and tailored cognitive behavioral therapy for anxiety and depression: a systematic review and meta-analysis of randomized controlled trials. Cognitive Behaviour Therapy, 46, 1-28. doi: 10.1080/16506073.2016.1231219

Patton, GC., Sawyer, SM., Santelli, JS., Ross DA., Afifi, R., Allen, NB., Arora, M., Azzopardi, P., Baldwin, W., Bonell, C., Kakuma, R., Kennedy, E., Mahon, J., McGovern, T., Mokdad, AH., Patel, V., Petroni, S., Reavley, N., Taiwo, K., Waldfogel, J., Wickremarathne, D., Barroso, C., Bhutta, Z., Fatusi, AO., Mattoo, A., Diers, J., Fang, J., Ferguson, J., Ssewamala, F. \& Viner, RM. (2016). Our future: a Lancet commission on adolescent health and wellbeing. Lancet, 387, 2423-78. http://dx.doi.org/10.1016/S0140-6736(16)00579-1 
Paxling, B., Almlöv, J., Dahlin, M., Carlbring, P., Breitholtz, E., Eriksson, T., \& Andersson, G. (2011). Guided internet-delivered cognitive behavior therapy for generalized anxiety disorder: a randomized controlled trial. Cognitive Behaviour Therapy, 40(3), 159-173. doi: 10.1080/16506073.2011.576699

Pearl, S. B., \& Norton, P. J. (2017). Transdiagnostic versus diagnosis specific cognitive behavioural therapies for anxiety: A metaanalysis. Journal of Anxiety Disorders, 46, 11-24. doi:10.1016/j.janxdis.2016.07.004

Porensky, E. K., Dew, M. A., Karp, J. F., Skidmore, E., Rollman, B. L., Shear, M. K., \& Lenze, E. J. (2009). The burden of late-life generalized anxiety disorder: Effects on disability, healthrelated quality of life, and healthcare utilization. American Journal of Geriatric Psychiatry, 17(6), 473-482. doi:10.1097/JGP.0b013e31819b87b2

Rapee, R.M., Schniering, C.A., \& Hudson, J.L., (2009). Anxiety disorders during childhood and adolescence: origins and treatment. Annual Review of Clinical Psycholgy, 5, 311-341. http://dx.doi.org/10.1146/annurev.clinpsy.032408.153628.

Rickwood, D., \& Bradford, S. (2012). The role of self-help in the treatment of mild anxiety disorders in young people: an evidence-based review. Psychology and Research Behavior Management, 5, 25-36. http://dx.doi.org/10.2147/PRBM.S23357.

Robinson, E., Titov, N., Andrews, G., McIntyre, K., Schwencke, G., \& Solley, K. (2010) Internet treatment for generalized anxiety disorder: a randomized controlled trial comparing clinician vs. technician assistance. PLoS One, 5(6): e10942. doi: 10.1371/journal.pone.0010942

Rozental, A., Andersson, G., Boettcher, J., Ebert, D. D., Cuijpers, P., Knaevelsrud, C., Ljótsson, B., Kaldo, V., Titov, N., \& Carlbring, P. (2014). Consensus statement on defining and measuring negative effects of Internet interventions. Internet Interventions, 1(1), 12-19. doi: 10.1016/j.invent.2014.02.001 
Roy-Byrne, PP., Davidson, KW., Kessler, RC., Asmundson, GJG.,

Goodwin, RD., Kubzansky, L., Lydiard, RB., Massie, MJ.,

Katon, W., Laden, SK., \& Stein, MB. (2008). Anxiety

disorders and comorbid medical illness. General Hospital

Psychiatry, 30, 208-225. doi:

10.1016/j.genhosppsych.2007.12.006.

Rutter, M., Bishop, D., Pine, D., Scott, S., Stevenson, J.S., Taylor, E.A., \& Thapar, A. (2012). Child and adolescent psychiatry, $5^{\text {th }}$ ed.

New York: Wiley Blackwell.

Salim, A., Mackinnon, A., Christensen, H., \& Griffiths, K. (2008).

Comparison of data analysis strategies for intent-to-treat

analysis in pre-test-post-test designs with substantial dropout rates. Psychiatry Research, 160, 335-345.

http://dx.doi.org/10.1016/j.psychres.2007.08.005.

Saunders, J.B., Aasland, O.G., Babor, T.F., de la Fuente, J.R., Grant, M., (1993). Development of the Alcohol Use Disorders Identification Test (AUDIT): WHO collaborative project on early detection of persons with harmful alcohol consumptionII. Addiction 88 (6), 791-804. http://dx.doi.org/10.1111/j.1360-0443.1993.tb02093.x.

Schuurmans, J., \& van Balkom, A. (2011). Late-life anxiety disorders: A review. Current Psychiatry Reports, 13, 267-273. doi:10.1007/s11920-011-0204-4

Seligman, L. D., \& Ollendick, T. H. (2011). Cognitive Behavioral Therapy for Anxiety Disorders in Youth. Child and Adolescent Psychiatric Clinics of North America, 20(2), 217-238. doi:10.1016/j.chc.2011.01.003.

Serlachius, E., Thulin, U., Andersson, G., Vigerland, V., Ivarsson, T. (2012). Ångeststörningar hos barn och ungdomar -hjälp finns att få. Läkartidningen, 109, 1946 - 1949.

Sethi, S., Campbell, A.J., \& Ellis, L.A. (2010). The use of computerized self-help packages to treat adolescent depression and anxiety. Journal of Technology in Human Services, 28, 144 - 160. http://dx.doi.org/10.1080/15228835.2010.508317 
Shear, MK., Brown, TA., Barlow, DH., Money, R., Sholomskas, DE., Woods, SW., Gorman, JM., \& Papp, LA. (1997). Multicenter collaborative panic disorder severity scale. The American Journal of Psychiatry, 154(11), 1571-1575. doi: 10.1176/ajp.154.11.1571

Shortt, A.L., Barrett, P.M., \& Fox, T.L., (2001). Evaluating the FRIENDS program: a cognitive behavioral group treatment for anxious children and their parents. Journal of Clinical Child Psychology, 30, 525-535. doi: 10.1207/S15374424JCCP3004 09

Shrestha, S., Robertson, S., \& Stanley, M. A. (2011). Innovations in research for treatment of late-life anxiety. Aging \& Mental Health, 15, 811-821. doi: 10.1080/13607863.2011.569487

Silfvernagel, K., Carlbring, P., Kabo, J., Edström, S., Eriksson, J., Månson, L., \& Andersson, G. (2012). Individually tailored internetbased treatment for young adults and adults with panic attacks: Randomized controlled trial. Journal of Medical Internet Research, 14, e65. doi: 10.2196/jmir.1853

Silfvernagel, K., Gren-Landell, M., Emanuelsson, M., Carlbring, P \& Andersson, G. (2012). Individually tailored internet-based cognitive behavior therapy for adolescents with anxiety disorders: A pilot effectiveness study. Internet Interventions, 2, 297-302. http://dx.doi.org/10.1016/j.invent.2015.07.002

Silverman, W.K., \& Albano, A.M., (1996). Anxiety Disorders Interview Schedule for DSM-IV child version: Parent interview schedule. Psychological Corporation, San Antonio, TX.

Skinner, B. F. (1938). The behavior of organisms. New York: AppletonCentury-Crofts.

Skoog, I. (2011). Psychiatric disorders in the elderly. Canadian Journal of Psychiatry, 56, 387-397. doi:10.1177/070674371105600702

Southam-Gerow, M.A.,Weisz, J.R., Chu, B.C., McLeod, B.D., Gordis, E.B., \& Connor-Smith, J.K. (2010). Does cognitive behavioral therapy for youth anxiety outperform usual care in community clinics? An initial effectiveness test. Journal of the American Academy of Child and Adolescent Psychiatry, 49, 1043-1052. http://dx.doi.org/10.1016/j.jaac.2010.06.009. 
Spek, V., Cuijpers, P., Nyklícek, I., Riper, H., Keyzer, J., Pop, V. (2007). Internet-based cognitive behaviour therapy for symptoms of depression and anxiety: a meta-analysis. Psychological Medicine, 37, 319-328. doi:10.1017/S003329170600894

Spence, S.H., Donovan, C.L., March, S., Gamble, A., Andersson, R.E., Prosser, S., Kenardy, J., (2011). A randomized controlled trial of online versus clinic-based CBT for adolescent anxiety. Journal of Consulting and Clinical Psychology, 79, 629-642. http://dx.doi.org/10.1037/a0024512.

Spitzer, R. L., Kroenke, K., Williams, J. B., \& Lowe, B. (2006). A brief measure for assessing generalized anxiety disorder: the GAD7. Archives of Internal Medicine, 166, 1092-1097. doi:10.1001/archinte.166.10.1092

Staples, L. G., Fogliati, V. J., Dear, B. F., Nielssen, O., \& Titov, N. (2016). Internet-delivered treatment for older adults with anxiety and depression: implementation of the Wellbeing Plus Course in routine clinical care and comparison with research trial outcomes. BJPsych Open, 2, 307-313. doi:10.1192/bjpo.bp.116.003400

Stirman, S W., DeRubeis, R J., Crits-Christoph, P., Brody, P E. (2003). Are Samples in Randomized Controlled Trials of Psychotherapy Representative of Community Outpatients? A New Methodology and Initial Findings. Journal of Consulting and Clinical Psychology, 71(6), 963-972. http://dx.doi.org.e.bibl.liu.se/10.1037/0022-006X.71.6.963

Svanborg, P., Åsberg, M., 1994. A new self-rating scale for depression and anxiety states based on the Comprehensive Psychopathological Rating Scale. Acta Psychiatrica Scanddinavia, 89(1), 21-28. http://dx.doi.org/10.1111/j.1600-0447.1994.tb01480.x.

Swedish National Board of Health and Welfare: Socialstyrelsen. (2009). Psykologisk behandling av psykiska besvär hos äldre - En kunskapssammanställning. Stockholm: Socialstyrelsen.

Swedish National Board of Health and Welfare: Socialstyrelsen (2013). Psykisk ohälsa bland unga. Underlagsrapport till Barns och ungas hälsa, vård och omsorg 2013. Stockholm 2013. 
Tillfors, M., Andersson, G., Ekselius, L., Furmark, T., Lewenhaupt, S., Karlsson, A., \& Carlbring, P. (2011). A randomized trial of internet-delivered treatment for social anxiety disorder in high school students. Cognitive Behaviour Therapy, 40, 147-157. doi:10.1080/16506073.2011.555486

Titov, N., Andrews, G., Johnston, L., Robinson, E., \& Spence, J. (2010). Transdiagnostic Internet treatment for anxiety disorders: A randomized controlled trial. Behaviour Research and Therapy, 48(9), 890-899. doi: 10.1016/j.brat.2010.05.014

Titov, N., Dear, BF., Ali, S., Zou, J., Lorian, C., Johnston, L., Terides, MD., Kayrouz, R., Klein, B., Gandy, M., \& Fogliati, V. (2015). Clinical and cost-effectiveness of clinician-guided internetdelivered cognitive behaviour therapy program for older adults with symptoms of depression: a randomised controlled trial. Behavior Therapy, 46, 193-205. doi: 10.1016/j.beth.2014.09.007

Titov, N., Gibson, M., Andrews, G., \& McEvoy, P. (2009). Internet treatment for social phobia reduces comorbidity. Australian \& New Zealand Journal of Psychiatry, 43(8), 754-759. doi: 10.1080/00048670903001992

Titov, N., Fogliati, V. J., Staples, L. G., Gandy, M., Johnston, L., Wootton, B., Nielssen, O., \& Dear, B. F. (2016). Treating anxiety and depression in older adults: randomised controlled trial comparing guided $\mathrm{v}$. self-guided internet-delivered cognitivebehavioural therapy. BJPsych Open, 2, 50-58. doi:10.1192/bjpo.bp.115.002139

Vernmark, K., Lenndin, J., Bjärehed, J., Carlsson, M., Karlsson, J., Oberg, J., Carlbring, C., Eriksson, T., \& Andersson, G. (2010). Internet administered guided self-help versus individualized email therapy: A randomized trial of two versions of CBT for major depression. Behaviour Research and Therapy, 48(5), 368-376. doi: 10.1016/j.brat.2010.01.005 
Vigerland, S., Lenhard, F., Bonnert, M., Lalouni, M., Hedman, E., Ahlen, J., Olén, O., Serlachius, E., Ljótsson, B. (2016). Internetdelivered cognitive behavior therapy for children and adolescents: A systematic review and meta-analysis. Clinical Psychology Review, 50, 1-10.

http://dx.doi.org/10.1016/j.cpr.2016.09.005

Vigerland, S., Thulin, U., Ljótsson, B., Svirsky, L., Bengtsson, O., Lindefors, N., Andersson, G., \& Serlachius, E. (2013). Datoriserad terapi för ångeststörning bör prövas även för barn och unga. Kan ge bättre tillgänglighet till evidensbaserad behandling. Läkartidningen, 110, 92 - 94

Vlaescu, G., Alasjö, A., Miloff, A., Carlbring, P., \& Andersson, G. (2016). Features and functionality of the Iterapi platform for internetbased psychological treatment. Internet Interventions, 6, 107114. doi: 10.1016/j.invent.2016.09.006

Watson, J. B., \& Rayner, R. (2000). Conditioned emotional reactions. 1920. American Psychologist, 55(3), 313-317.

Wenar, C., \& Kerig, P. (2008). Developmental psychopathology. From infancy through adolescence. Fifth Edition. New York: McGraw Hill International Edition.

Westbrook, D., Kennerly, H., \& Kirk, J. (2011). Cognitive behaviour therapy. Skills and applications, $2^{\text {nd }}$ edn. Sage, Los Angeles

Wilkinson, P. (2013). Cognitive behavioural therapy with older people. Maturitas, 76(1), 5-9. doi: 10.1016/j.maturitas.2013.05.008

Wolitzky Taylor, K. B., Castriotta, N., Lenze, E. J., Stanley, M. A., \& Craske, M. G. (2010). Anxiety disorders in older adults: a comprehensive review. Depression and anxiety, 27(2), 190211. doi: 10.1002/da.20653

Woody, SR. \& Ollendick, TH. Technique factors in treating anxiety disorders. In: Castonguay, L.; Beutler, LE., editors. Principles of therapeutic change that work. New York: Oxford University Press; 2006. p. 167-186. 
Zou, JB., Dear, BF., Titov, N., Lorian, CN., Johnston, L., Spence, J., Knight, RG., Anderson, T., \& Sachdev, P. (2012). Brief internet-delivered cognitive behavioural therapy for anxiety in older adults: a feasibility trial. Journal of Anxiety Disorders, 26, 650-655. doi: 10.1016/j.janxdis.2012.04.002 


\section{Acknowledgments}

Jag vill rikta ett stort tack till Gerhard Andersson, min huvudhandledare, som trodde på mina idéer redan under tiden på psykologprogrammet vid Linköpings Universitet. Du erbjöd mig möjligheten att ta körkortet som forskare och tillsammans skapade vi en plan för de år som skulle bli min doktorandtid. Jag är stolt över att vara en del av din forskargrupp och den frihet du erbjudit mig under åren. Du har uppmuntrat mig till samarbeten inom och utanför Linköpings Universitet och alltid visat mig stor tillit. Du är noga med att visa din uppskattning för det jag bidrar med, vilket gör att jag ständigt förstärks i att jag är på rätt plats.

Malin Gren Landell, tack för den kliniska kunskap du erbjudit mig under åren. Tack för att du bidragit med din kunskap om barn och ungdomar med ångest. Du har inte bara varit min biträdande handledare för avhandlingen utan även min kliniska handledare under åren jag spenderade inom Barnoch ungdomsspykiatrin, ett stort tack även för detta.

Per Carlbring, du har funnits med från start, både min biträdande handledare för min examensuppsats på psykologprogrammet såväl som för avhandlingen. Du har alltid funnits max ett telefonsamtal bort. Tack för handledning i statistik och för dina bidrag i studierna. Tack för att du alltid nickar och ler som du gör när jag är lite extra nervös under en presentation.

Under större delen av min tid på Linköpings Universitet har min främsta finansiär varit professorskontraktet som Gerhard Andersson innehar. Hälsooch sjukvårdsnämnden i Östergötland, FORSS samt FORTE har även dem agerat finansiärer, tack för att ni trodde på våra idéer.

Jag vill rikta ett stort tack till mina medförfattare: Julia Kabo, Sara Edström, Jenny Zettersten, Lisa Månson, Carolina Wassermann, Marie Emaunelsson, Anna Westlinder, Stina Andersson, Kajsa Bergman, Rosario Diaz Hernandez, Line Fallhagen, Ida Lundqvist, Nicole Masri, Linda Viberg, Marie-Louise Forsberg och Maria Lind. Tack för all tid ni lagt ner i respektive projekt. 
I would like to thank Thomas Berger, one of my coauthors for Paper IV. Thank you for your help with WCST and for always making me laugh with your emails. I hope to see you soon.

Tack Miriam Fohlin, Malin Larsson och Asa Johansson för ert bidrag till studien vi genomförde på Ungdomshälsan.

Tack till alla deltagare i de fyra studier denna avhandling består av, utan er, ingen avhandling.

Jag vill rikta ett stort tack till Lars-Göran Öst för möjligheten att använda ADIS i Paper I, tack för utbildning och förtroende.

Tack Viktor Kaldo och Erik Andersson, för värdefulla råd och givande diskussioner i samband med mitt halvtids- och slutseminarium.

Lise Bergman Nordgren, min extra handledare. Du är en av dem som fått mig att känna mig hemma inom forskningen. I stunder när jag tvivlat har du pushat mig framåt och det har gjort att jag växt. Jag har stor respekt för dig som forskare och medmänniska. Du är en av mina förebilder men samtidigt känner jag mig alltid som en kollega i din närvaro.

Maria Jannert, min kliniska förebild och goda vän. Att nu även vara din kollega på psykologmottagningen, att dela ansvar och verksamhetsutveckling med dig ger mig väldigt mycket glädje i min vardag. Tack för att du alltid visat mig stort förtroende, såväl när jag var student på psykologprogrammet som alla de gånger jag tagits in som lärare på dina moment.

Robert Johansson, tack för dina värdefulla synpunkter och konkreta råd. Tack särskilt för samtalet den 14:e januari 2016.

Tack Alexander Alasjö för dina bidrag till de studier denna avhandling består av. Tack George Vlaescu, tack för ett gott sammarbete, tack för givande diskussioner och för att du hjälpt mig implementera mina idéer $\mathrm{i}$ studier utanför denna avhandling. 
Stort tack till forskargruppen, tack Naira Topooco och Matilda Berg för att ni kommit med värdefulla kommentarer på avhandlingen. Tack Kristoffer Månsson, min rumskamrat med en annan musiksmak än min. Det har varit ett sant nöja att arbeta med dig under åren. Tack till dig, Robert Persson Asplund, för våra diskussioner om de ämnen som är särskilt viktiga för oss. Till Jesper Dagöö, tack för det vi delat tillsammans. Tack till Hoa Ly som alltid bidragit med energi dessa år. Tack till Peter Molander, en förebild på många sätt, framförallt $\mathrm{i}$ hur du balanserar dina två miljöer. Tack till Elisabeth Ingo, är oerhört glad att du blev en del av vår forskargrupp. Tack till Hugo Hesser för att du utmanat mig i mitt tänkade både i rollen som kollega och under den kurs jag gått för dig. Tack till Kristofer Vernmark, för att du uppdaterar oss vad som händer inom vårt fält ute i klinik.

Jag vill rikta ett stort tack till Britt-Marie Alfredsson-Svensson, tack för dina påminnelser och särskilt för det stöd du erbjuder $i$ slutfasen av doktorandtiden. Det är oerhört värdefullt och jag är väldigt tacksam, för med din hjälp har inget upplevts som krångligt.

Guy Cathro, thank you for reading my thesis and for offering valuable advice.

Ett stort tack till Erika Viklund, det är en ynnest att vara lärare på dina kurser.

Tack till alla mina kollegor på avdelningen för psykologi. Tack Ellinor Sellgren, du är en värdefull kollega och vän. Tack Åsa Wrede, självklart även tack till Minka och Kaia för våra promenader.

Tack till alla studenter i alla studier jag varit med och handlett utanför avhandlingsarbetet.

Linda Snecker, koordinatorn som blev min bästa vän.

Per Persson, tack för samtal, för tystnaden, för allvar och för skratt. Tack för den värme och omtanke du alltid visar mig. 
Rebecka Persson, tack för att du tålmodigt handledde mig i utredningsarbetet under tiden inom Barn- och ungdomsspykiatrin. Vi har delat mycket tillsammans under de senaste åren, såväl vänskap, artiklar och nu motorcyklar.

Åke Suneson, tack för de år vi fick tillsammans, tack för att du bjöd in mig till er underbara familj från start. Stora delar av denna avhandling har skrivits där du trivdes som allra bäst, med skogen bakom och sjön framför mig. Du saknas oss.

Tack till Jenny, Pär, Leonie och Thea Wissmark, Christina Suneson, Eva och Fredrik Lundström, min utökade familj. Tack för att ni gör vardagen till de bästa av stunder.

Tack till Arla Löthberg, Linda Sorby och Christer Nystedt för att ni är en del av min familj.

Mina bröder, Patrik Silfvernagel och Fredrik Silfvernagel, tack för att ni alltid stöttat mig att gå min egen väg. Mia Silfvernagel och Helena Silfvernagel, mina extra storasystrar, tack för ert fina stöd genom livet. Edvin Silfvernagel, Ville Silfvernagel, Henry Silfvernagel och Leo Silfvernagel, mina brorsöner, jag är så glad över att får vara er faster, jag är så oerhört stolt över er.

Mamma och pappa, utan er, inget jag.

Peter Suneson, mitt allt, jag älskar dig mer än något annat. 


\section{Papers}

The articles associated with this thesis have been removed for copyright reasons. For more details about these see:

http://urn.kb.se/resolve? urn:nbn:se:liu:diva-135823 


\section{LINKOPING STUDIES IN BEHAVIOURAL SCIENCE}

166. SANDBERG, FREDRIK. Recognition of Prior Learning in Health Care. From a Caring Ideology and Power, to Communicative Action and Recognition. 2012. ISBN: 978-91-7519-814-9

167. FÄGERSTAM, EMILIA. Space and Place. Perspectives on Outdoor Teaching and Learning. 2012. ISBN: 978-91-7519-813-2

168. FALKENSTRÖM, FREDRIK. The Capacity for Self-Observation in Psychotherapy. 2012. ISBN: 978-91-7519-797-5

169. BENNICH, MARIA. Kompetens och kompetensutveckling i omsorgsarbete. Synen på kompetens och lärande i äldreomsorgen - i spänningsfältet mellan samhälleliga förutsättningar och organisatoriska villkor. 2012. ISBN: 978-91-7519-777-7

170. RUSANGANWA, JOSEPH. Enhancing Physics Learning through Instruction, Technical Vocabulary and ICT. A Case of Higher Education in Rwanda. 2012. ISBN: 978-91-7519-739-5

171. MBABAZI, PENELOPE. Quality in Learning in Rwandan Higher Education: Different Stakeholders' Perceptions of Students' Learning and Employability. 2013. ISBN: 978-91-7519-682-4

172. BYSTRÖM, ERICA. Ett lärorikt arbete? Möjligheter och hinder för undersköterskor att lära och utvecklas i sjukvårdsarbetet. 2013. ISBN: 978-917519-679-4

173. KAGWESAGE, ANNE MARIE. Coping with Learning through a Foreign Language in Higher Education in Rwanda. 2013. ISBN: 978-91-7519-640-4

174. MUTWARASIBO, FAUSTIN. Understanding Group-based Learning in an Academic Context: Rwandan Students' Reflections on Collaborative Writing and Peer Assessment. 2013. ISBN: 978-91-7519-633-6

175. MÅRDH, SELINA. Cognitive erosion and its implications in Alzheimer's disease. 2013. ISBN: 978-91-7519-612-1

176. HARLIN, EVA-MARIE. Lärares reflektion och professionella utveckling Med video som verktyg. 2013. ISBN: 978-91-7519-611-4

177. ÖSTERGREN, RICKARD. Mathematical Learning Disability. Cognitive Conditions, Development and Predictions. 2013. ISBN: 978-91-7519-565-0 
178. ENGVALL, MARGARETA. Handlingar i matematikklassrumet. En studie av undervisningsverksamheter på lågstadiet då räknemetoder för addition och subtraktion är i fokus. 2013. ISBN: 978-91-7519-493-6

179. JOHANSSON, ROBERT. Treating depression and its comorbidity. From individualized Internet-delivered cognitive behavior therapy to affectfocused psychodynamic psychotherapy. 2013. ISBN: 978-91-7519-467-7

180. BERGMAN NORDGREN, LISE. Individually tailored internet-based cognitive behavioural therapy for anxiety disorders. 2013. ISBN: 978-917519-459-2

181. FREJD, PETER. Modes of Mathematical Modelling. An Analysis of how modelling is used and interpreted in and out of school settings. 2014. ISBN: 978-91-7519-414-1

182. AMAN, ROBERT. Impossible Interculturality? Education and the Colonial Difference in a Multicultural World. 2014. ISBN: 978-91-7519-348-9

183. NYLANDER, ERIK. Skolning i jazz. Värde, selektion och studiekarriär vid folkhögskolornas musiklinjer. 2014. ISBN: 978-91-7519-347-2

184. GRADIN FRANZÈN, ANNA. Disciplining freedom: Treatment dilemmas and subjectivity at a detention home for young men. 2014. ISBN: 978-917519-344-1

185. ENGSTRÖM, ANNIKA. Lärande samspel för effektivitet. En studie av arbetsgrupper i ett mindre industriföretag. 2014. ISBN:978-91-7519-345-8

186. ELWÉR, ÅSA. Early Predictors of Reading Comprehension Difficulties. 2014. ISBN: 978-91-7519-281-9

187. LARSON, NICLAS. Matematikämnet och stadiebytet mellan grundskolan och gymnasieskolan. En enkät- och klassrumsstudie. 2014. ISBN: 978-917519-196-6

188. LY, HOA. Use of a Smartphone Application in the Treatment of Depression - The New Wave of Digital Tools for Psychological Treatment. 2015. ISBN: 978-91-7519-136-2

189. HANSSON, PER-OLOF. New ways of learning. Participatory action research and Kenyan runners' appropriation of smartphones to improve their daily lives and participation in m-learning. 2015. ISBN: 978-91-7519124-9 
190. BOLLDÈN, KARIN. Online teaching practices. Sociomaterial matters in higher education settings. 2015. ISBN: 978-91-7519-123-2

191. MALMQUIST, ANNA. Pride and Prejudice. Lesbian families in contemporary Sweden. 2015. ISBN: 978-91-7519-087-7

192. AVBY, GUNILLA. Evidence in Practice. On Knowledge Use and Learning in Social Work. 2015. ISBN: 978-91-74519-088-4

193. FORSBERG, CAMILLA. Students' Perspectives on Bullying. 2016. ISBN: 978-91-7685-874-5

194. MUHRMAN, KAROLINA. Inget klöver utan matematik. En studie av matematik i yrkesutbildning och yrkesliv. 2016. ISBN: 978-91-7685-851-6

195. SKAGERLUND, KENNY. Magnitude Processing in Developmental Dyscalculia. A Heterogeneous learning disability with different cognitive profiles. 2016. ISBN: 978-91-7685-831-8

196. EKEBLAD, ANNIKA. A Randomized Trial of Interpersonal Psychotherapy and Cognitive Behavioral Therapy for Major Depressive Disorder Predictors of process and outcome. 2016. ISBN: 978-91-7685-803-5

197. MÅSSON, KRISTOFFER N.T. Restructuring the Socially Anxious Brain. Using magnetic resonance imaging to advance our understanding of effective cognitive behaviour therapy for social anxiety disorder. 2016. ISBN: 978-91-7685-688-8 